\title{
LAS RUTAS HISTÓRICAS DEL DESARROLLO DE LAS CIENCIAS BIOLÓGICAS EN COSTA RICA
}

\author{
The historical routes of the development of biological sciences in Costa Rica

Luko Hilje Quirós $^{1}$
Centro Agronómico Tropical de Investigación y Enseñanza (CATIE), Costa Rica
luko@ ice.co.cr

Recibido: $15-09-2021$

Aprobado: 13-11-2021

Luko Hilje Quirós es Licenciado en Biología y doctor en Entomología, miembro de la Asamblea de Fundadores del Instituto Nacional de Biodiversidad (INBio) y miembro honorario del Colegio de Ingenieros Agrónomos de Costa Rica. Es Profesor Emérito del Centro Agronómico Tropical de Investigación y Enseñanza (CATIE), Turrialba, Costa Rica.

\section{RESUMEN}

En este artículo se analizan los factores y circunstancias naturales, económicos, sociales y políticos que han conducido a la institucionalización y la consolidación de las ciencias biológicas en Costa Rica, en dos siglos de vida independiente, a la vez que se resaltan los aportes de los principales individuos y entidades que han hecho posible dicho proceso. Para abordar este análisis, se identifican las siguientes seis rutas históricas clave: la condición ístmica del país y la cercanía del río San Juan, por su importancia potencial como un canal interoceánico natural; la paz y la estabilidad política del país, como una condición para hacer ciencia; el reconocimiento y la aceptación de las ciencias biológicas en la cultura local; la visión y la necesidad de nutrirse del conocimiento científico extranjero; las oportunas y fecundas alianzas científicas internacionales; y la conciencia de la necesidad de institucionalizar las ciencias biológicas. Es de esperar que de este análisis se deriven lecciones que contribuyan a orientar mejor los futuros esfuerzos nacionales en este campo.

Palabras clave: Independencia, Bicentenario, Ciencias naturales, Institucionalización, Redes científicas, Universidades, Colaboración internacional.

This article analyzes natural, economic, social and political factors and circumstances that have been conducive to the institutionalization and consolidation of biological sciences in Costa Rica, in two centuries of independent life, while highlighting the contributions of the main individuals and entities that have made this process possible. The following six key historical routes have been identified to tackle this analysis: the isthmic condition of the country and the proximity of the San Juan River, due to its potential importance as a natural interoceanic canal; the peace and political stability of the country, as a condition for carrying out scientific activities; the recognition and acceptance of biological sciences in the local culture; the vision and need to take advantage of foreign scientific knowledge; opportune and fruitful international scientific alliances; and awareness of the need to institutionalize biological sciences. Hopefully, lessons may be derived from this analysis, geared to contribute to better orient future national efforts in this matter.

Keywords: Independence, Bicentenary, Natural sciences, Institutionalization, Scientific networks, Universities, International collaboration.

\footnotetext{
${ }^{1}$ Profesor Emérito, Centro Agronómico Tropical de Investigación y Enseñanza (CATIE).
} 
Revista Herencia, Vol. 35 (1), enero-junio, 2022.

\section{Introducción}

Es evidente que el desarrollo de la ciencia en general, así como el de las ciencias biológicas en particular, no puede ni debe disociarse del acontecer económico, social y político de un país. Al respecto, en el caso de Costa Rica, aún hoy no se ha intentado realizar un análisis de las circunstancias históricas que han hecho posible el proceso que ha conducido al reconocimiento, la institucionalización y la consolidación de las ciencias biológicas, como una meta o aspiración nacional.

Por tanto, en el marco de la celebración del Bicentenario de nuestra independencia, en este artículo se presenta un análisis de dicho proceso, orientado a dilucidar los factores, causas, hechos y condiciones que han propiciado la construcción de las seis rutas que - a nuestro entender - han permitido el desarrollo de las ciencias biológicas en Costa Rica; obviamente, todas están interconectadas, en mayor o menor medida. Es de esperar que, aunque sin ser exhaustivo, de este análisis se deriven lecciones y aprendizajes que contribuyan a orientar mejor los futuros esfuerzos nacionales en este campo.

Antes de empezar, es pertinente señalar que la mayor parte de la información aquí contenida proviene de las amplias revisiones de González (1976), Gómez y Savage (1986), Kandler (1987), León (2002), Grayum et al. (2004), Zeledón (2004), Hilje (2013a, 2015), Boza (2015), Díaz (2016) y Ossenbach (2016), así como de otras publicaciones clave, tanto de carácter biológico (Conejo, 1975; Jirón y Vargas, 1986; Bussing, 1987; Eakin, 1999; MongeNájera y Méndez-Estrada, 2002; Rodríguez, 2002; Savage, 2002; Díaz y Solano, 2009; García, 2009; Salazar, 2009; Casto y Burke, 2010; Oersted, 2011; Hilje, 2013b; May, 2013; Dauphin, 2020) como propiamente histórico (Torres-Rivas, 1989; Quesada, 2001; Obregón, 2002; Molina, 2007), por lo que su mención se ha omitido en el cuerpo del texto. No obstante, se incluyen otras referencias en casos puntuales, cuando se considera pertinente.

\section{Dos rasgos geomorfológicos favorables}

\section{Un providencial istmo}

El territorio de Costa Rica no ha existido siempre, sino que en su espacio actual lo que había era un vasto paraje marino, donde se entremezclaban las aguas del actual mar Caribe con las del océano Pacífico. No obstante, fue gracias a varios procesos geológicos y volcánicos ocurridos a lo largo de miles o millones de años como se formó un istmo o puente, el cual conectó las grandes masas terráqueas de Norte y Suramérica. Esto aconteció hace unos tres millones de años, en la época del Plioceno (Valerio, 2006).

Sin embargo, además de hacer posible tan imprevista pero providencial interconexión terrestre entre ambos subcontinentes, ese istmo terráqueo se convirtió en un puente biológico, que permitió la migración de especies vegetales y animales de origen norte o suramericano en sentidos opuestos, de modo que resultó poblado por dichos organismos. Además, gracias al fenómeno de la especiación —que es parte del proceso de evolución orgánica—, surgieron centenares o miles de especies endémicas o propias de Costa Rica, o de ésta y sus dos países 
Revista Herencia, Vol. 35 (1), enero-junio, 2022.

colindantes; aunque estas cifras habrán de cambiar conforme se profundice en los inventarios en ambos países limítrofes; por ahora se calcula en al menos 1500 especies el número de plantas y animales endémicas de Costa Rica, junto con Nicaragua, Panamá, o ambos juntos.

Ahora bien, la condición ístmica ha conferido a Costa Rica el privilegio de ser parte de un área biogeográfica de gran importancia mundial. Bien se puede afirmar que el territorio nacional es muy rico en biodiversidad, o megadiverso, a pesar de su pequeño tamaño (51.085 $\mathrm{km}^{2}$ ), al punto de que alberga más del $4 \%$ del total mundial de especies de plantas y animales (Valerio, 2006). Sin embargo, con la conquista de parte del Imperio Español, no recibió mayor atención, por razones que se analizarán posteriormente.

Al respecto, cabe acotar que la primera de las expediciones españolas, la cual comenzó en 1571 y se prolongó por seis años, fue liderada por el médico, botánico y ornitólogo Francisco Hernández de Toledo; se concentró en Nueva España (México). Más de dos siglos después, se efectuarían dos prolongadas exploraciones a América del Sur, como lo fueron la Real Expedición Botánica al Virreinato del Perú (1777-1788), encabezada por el botánico y farmacéutico Hipólito Ruiz, al igual que la Real Expedición Botánica del Nuevo Reino de Granada (Colombia) (1783-1816), dirigida por el cura, botánico y matemático José Celestino Mutis.

Finalmente, tendría lugar la Real Expedición Botánica a la Nueva España (1787-1803), conducida por el médico y botánico Martín de Sessé, junto con Vicente Cervantes Mendo y el mexicano José Mariano Mociño. Como parte de esta última expedición, que se extendió por 16 años, Mociño tuvo la oportunidad de visitar algunas islas del Caribe y una porción de América Central, incluyendo Costa Rica, pero de manera apenas marginal, aunque parece que ingresó hasta Cartago, pero brevemente. Como una curiosidad, hay evidencias de la presencia fugaz, antes de estas amplias exploraciones, de dos británicos; uno fue William Dampier, bucanero y aficionado a las plantas, que en 1684 recolectó plantas en la isla del Coco y en Cabo Blanco, y el otro fue el médico y botánico Archibald Menzies, quien en 1794 o 1795 herborizó en la isla del Coco.

Nótese que, hasta entonces, las herborizaciones fueron breves, o restringidas al litoral y a la isla del Coco. No obstante, esta desventaja inicial sería superada en el curso del tiempo, como se verá pronto. Y, por el contrario, Costa Rica se convertiría en un país sumamente atractivo para los naturalistas y los biólogos interesados en conocer e inventariar nuestras flora y fauna, así como en estudiar sus relaciones taxonómicas y ecológicas, al igual que sus aspectos genéticos y evolutivos. Estos últimos aspectos datan ya de los siglos XX y XXI, gracias a las relaciones establecidas sobre todo entre las universidades nacionales y científicos extranjeros. Al respecto, quizás su expresión más fehaciente fue la fundación del Instituto Nacional de Biodiversidad (INBio), una entidad centrada en la exploración, el conocimiento, la conservación y la utilización de la biodiversidad de Costa Rica (genes, especies y ecosistemas), a la que se aludirá con más detalle posteriormente.

En efecto, el INBio logró atraer los intereses de un numeroso grupo de renombrados taxónomos, a quienes se les remitían los especímenes de plantas y animales recolectados por numerosos jóvenes rurales recolectores (parataxónomos) adiestrados por taxónomos 
Revista Herencia, Vol. 35 (1), enero-junio, 2022.

nacionales, especialmente aquellos especímenes no identificados por los especialistas nacionales. En otros casos, una vez que había suficiente material acumulado, los propios taxónomos venían al país para identificar las muestras, sin cobrar nada al INBio. Como resultado de este innovador esquema de colaboración, se pudieron recolectar e identificar más de 2.000.000 de especímenes de insectos, plantas, hongos y moluscos, con al menos 3700 especies nuevas para la ciencia. Sin duda, ha representado la más grande colección biológica efectuada en la historia del país.

Gracias a este innovador e ingente esfuerzo, así como a los de numerosos investigadores previos, hoy sabemos que en los territorios terráqueo y marino de Costa Rica hay 3873 especies de hongos y líquenes, 11.535 de plantas, 69.109 de insectos, 5898 de otros invertebrados, 1187 de peces dulceacuícolas y marinos, 201 de anfibios, 238 de reptiles, 909 de aves y 249 de mamíferos (Obando y Bermúdez, 2020); cabe acotar que, en cuanto a las plantas, según el experto Michael H. Grayum, la cifra es levemente menor, de unas 11.000 especies, incluyendo los helechos. Sin embargo, según los expertos, las cifras reales de todos los organismos deben ser muy superiores, lo cual significa que, si las labores de inventario continúan por varios decenios, se esperaría que hubiera cerca de 365.000 especies de insectos y 17.235 de otros invertebrados, más las especies marinas, muchas por descubrir y describir.

Un hecho por destacar en cuanto a la biodiversidad es que, gracias a los sorprendentes hallazgos del biólogo estadounidense Daniel H. Janzen en años recientes en Costa Rica, se ha podido determinar, mediante un método molecular denominado en inglés "DNA barcoding", que algunas especies de mariposas y polillas que son idénticas a simple vista, no lo son en sus características genéticas, de modo que en realidad corresponden a especies distintas (Janzen y Hallwachs, 2016). Esto podría tener consecuencias biológicas, ecológicas y evolutivas de varios tipos, incluyendo su conservación o manejo, pero en términos de la riqueza de especies de Costa Rica significa que ésta se acrecentaría aún más, no solo para lepidópteros, sino también para otros grupos de animales y plantas.

\section{Un canal interoceánico natural}

Ahora bien, la propia condición ístmica le confirió otra ventaja a Costa Rica, junto con su vecina Nicaragua. De manera indisoluble a la estrechez del territorio limítrofe entre ambos países, las características geomorfológicas del territorio dieron origen a un amplio drenaje o desaguadero hacia el mar Caribe, a partir del gran lago de Cocibolca o Nicaragua. Ese cauce fluvial, que después sería bautizado río San Juan, fue visualizado por varias potencias económicas (Inglaterra, Francia y EE.UU.) como la vía natural — casi un regalo de la Naturaleza - para abrir un canal interoceánico, de inmenso valor geo-estratégico y económico, pues permitiría la agilización del comercio mundial, y a costos menores, como en efecto sucedería con el canal de Panamá a partir de su inauguración, en 1914.

De hecho, tan temprano como 1523, el rey Carlos I le había advertido al conquistador Hernán Cortés — afincado en México - lo siguiente: "Y porque soy informado que en la costa abajo de esa tierra hay un estrecho pasar en la mar del Norte a la mar del Sur, e porque a nuestro servicio conviene mucho savello, yo os encargo y mando que luego con mucha diligencia procuréis saber si ay el dicho estrecho y enviéis personas que lo busquen e os traigan larga 
Revista Herencia, Vol. 35 (1), enero-junio, 2022.

e verdadera relación de lo que en ello se hallase porque como beis esto es una cosa muy importante a nuestro servicio".

Mítico y tentador como era ese "estrecho dudoso" - llamado así por los conquistadores-, ya liberadas las repúblicas centroamericanas del Imperio Español, a partir de 1836 y por siete años sus costas fueron prolijamente mapeadas por Inglaterra, que envió al capitán Sir Edward Belcher al mando del barco HMS Sulphur, para cumplir esta misión. Para fortuna del desarrollo de nuestras ciencias biológicas, en dicha expedición se recolectaron plantas y animales, a cargo de los médicos Andrew Sinclair y Richard Brinsley Hinds, así como de George Barclay, empleado del célebre jardín botánico de Kew, en Londres. Sin embargo, sus herborizaciones en Costa Rica fueron escasas.

La noticia de un eventual canal interoceánico se difundió ampliamente por Europa, y también atrajo a naturalistas, que arribaron por cuenta propia. Fue así que, interesado en el posible canal, así como en las ruinas mayas de Yucatán, en México (Taracena y Sellen, 2006), en 1839 llegó a Costa Rica Emanuel Ritter von Friedrichsthal, botánico aficionado que fungiera como agregado diplomático en la legación de Austria en EE.UU.; estuvo apenas unas semanas, pero efectuó importantes recolecciones en varios puntos del país. Asimismo, después de permanecer un año en las islas Vírgenes y Jamaica, en setiembre de 1846 arribó el zoólogo y botánico danés Anders S. Oersted (Figura 1A). Poco antes había estado en Nicaragua, quizás interesado en realizar exploraciones botánicas en las áreas aledañas al eventual canal, a partir del puerto caribeño de San Juan del Norte o Greytown, pero después viajó hacia Costa Rica, donde se estableció.

Figura 1. Los primeros naturalistas residentes: Oersted (A), Hoffmann (B), von Frantzius (C) y Carmiol (D).
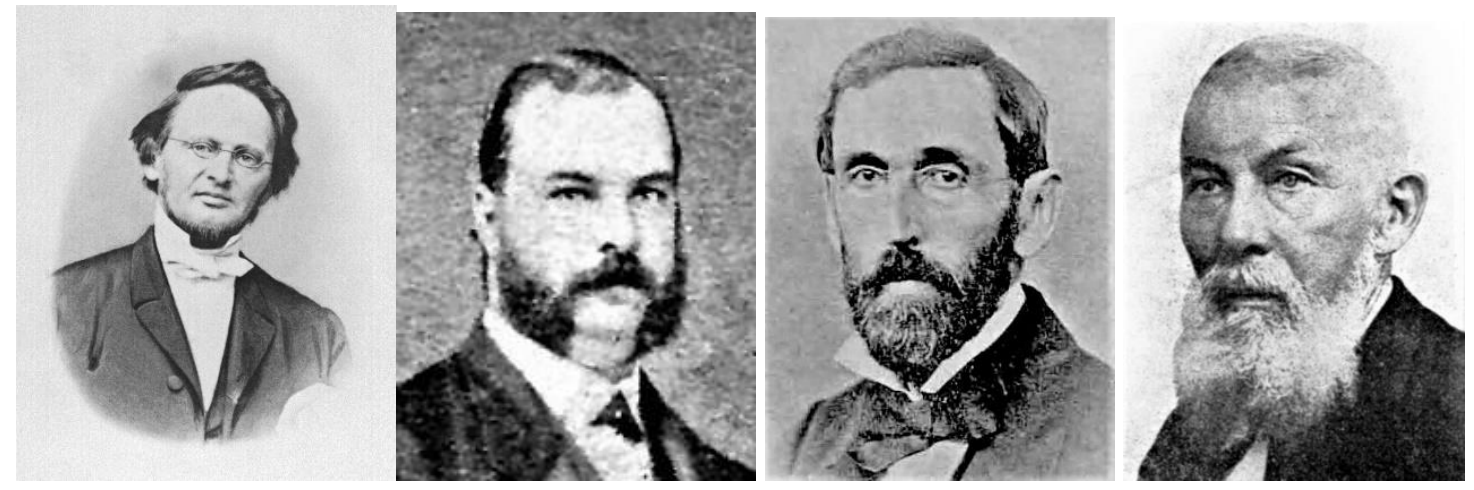

El mismo año en que Oersted partió, en Europa alcanzó el clímax la llamada Revolución de 1848, contra el poder monárquico absoluto. Sin embargo, no dio los frutos esperados y, además de la pobreza generalizada, sobrevino una implacable represión policial, forzando a grandes masas de ciudadanos a emigrar hacia América. En la búsqueda de una especie de válvula de escape para tanta tensión social y política, se creó la Sociedad Berlinesa de Colonización para Centro América, que era una iniciativa público-privada que pretendía establecer colonias de alemanes en suelo ístmico. Inicialmente pactaron una alianza con una colonia belga que había en Guatemala, pero el proyecto fracasó tiempo después. Posteriormente hubo tentativas en 
Revista Herencia, Vol. 35 (1), enero-junio, 2022.

Bluefields, Nicaragua, y Miravalles, en Guanacaste, en ambos casos relativamente cerca de la cuenca del río San Juan, con vistas a la construcción de un canal interoceánico por parte de alguna de las potencias de entonces.

Aunque ambos intentos abortaron, se planeó establecer una colonia alemana en Angostura, Turrialba, vinculada con la apertura de un puerto en el Caribe (Hilje, 2020). Y fue así como, en el mismo bergantín que traía a un numeroso grupo de personas para dicha colonia, a inicios de 1854 llegaron los médicos y naturalistas Karl Hoffmann y Alexander von Frantzius, así como el maestro-jardinero Julián Carmiol (Figuras 1B-D); los dos primeros habían participado en la insurrección de 1848, al igual que numerosos científicos e intelectuales. Aunque la colonia de Angostura fracasó pronto, ellos permanecieron en el país, donde harían invaluables aportes, algunos de los cuales serán descritos después.

En síntesis, la atracción del anhelado canal interoceánico influyó de manera directa o indirecta en el arribo de destacados naturalistas.

La información que ellos acopiaron se sumó a los aportes científicos logrados por la exploración del capitán Belcher, así como por dos expediciones biológicas previas del Imperio Español; aunque los españoles se concentraron en México, la región tropical de este país tiene muchas especies en común con el resto de Mesoamérica. De esta manera, para mediados del siglo XIX, empezó a consolidarse un importante cúmulo de conocimientos sobre nuestras flora y fauna.

\section{Un imán para los naturalistas}

Este acervo de información biológica se acrecentaría en años venideros y de manera paulatina, gracias a los aportes de varios naturalistas que arribaron a nuestras costas, casi siempre de manera individual e independiente. En efecto, además de los ya citados (von Friedrichsthal, Oersted, Hoffmann, von Frantzius y Carmiol), entre mediados del siglo XIX y 1957 - año de la llamada Reforma de la Universidad de Costa Rica, de la cual se hablará después-, llegaron numerosos europeos y estadounidenses, quienes permanecieron por períodos variables en el país, algunos hasta su muerte; la mayoría eran itinerantes, y estuvieron apenas de paso, a veces por unos pocos días.

A continuación, aparecen los nombres, los grupos biológicos de su interés —algunos eran recolectores por afición, sin formación científica - y el año en que cada explorador recorrió nuestro territorio; en algunos casos hay varias fechas, pues vinieron más de una vez. Es muy posible que, dada la dispersión de la información, así como la dificultad de seguir el rastro a cada uno de los exploradores visitantes, en la siguiente enumeración haya algunas omisiones. Además, algunos no estuvieron en el territorio continental, sino en la isla del Coco, y por muy breve tiempo.

Entre los europeos, arribaron el polaco Josef von Warszewicz (1848) (Figura 2A); los alsacianos Augustus R. Endrés (1867-1874) (Figura 2B) y Carlos Wercklé (1897, 1902-1924); los alemanes Carl Kramer (1866), Gottlieb Zahn (1869), Otto Kuntze (1874), Helmuth Polakowsky (1875-1876), Friedrich Carl Lehmann (1882), Anton Huebsch (1886), Alfredo 
Revista Herencia, Vol. 35 (1), enero-junio, 2022.

Brade (1892-1955), Alexander Curt Brade (1908-1910), Clarence K. Horich (1957-1994) y Hans Weber (1957); los suizos Henri Pittier (1887-1904), Adolphe Tonduz (1889-1921) y Walter Kupper (1931-1932); los suecos Alfredo Anderson (1894-1936) y Carl Bovallius (1886); y los ingleses Thomas Richard Archer Briggs (1856), George Downton (1871) y Charles H. Lankester (1900-1920, 1922-1969). Aunque todos eran botánicos, von Warszewicz y Endrés también recolectaron colibríes y otros animales vertebrados, en tanto que Lankester acopió insectos.

Asimismo, a ellos se sumaron dos franceses, el médico Eduardo Marchant Bonnecourt (18501858) y el ornitólogo Adolphe Boucard (1876); el entomólogo y malacólogo suizo Paul Biolley (1886-1908); y el mastozoólogo y ornitólogo inglés Cecil F. Underwood (1889-1943). Además, en el país residieron los entomólogos alemanes Heinrich Schmidt (1897-1948), Ferdinand Nevermann (1920-1937) y Alexander Bierig (1938-1954).

Figura 2. Algunos naturalistas clave, por sus aportes: von Warszewicz (A), Endrés (B), Standley (C) y Calvert (D).
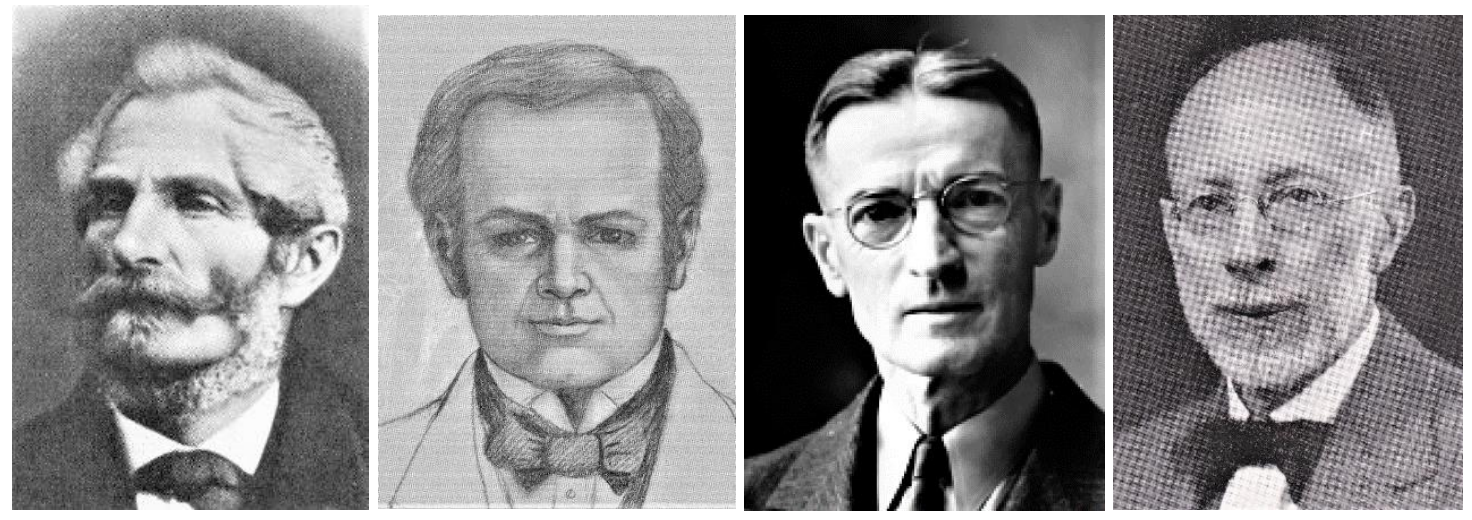

Por su parte, entre los estadounidenses llegaron los botánicos Sutton Hayes (1860), William C. Shannon (1893), John Donnell Smith (1894, 1896), William Ralph Maxon $(1906,1923)$, Orator Fuller Cook (1910s), Conrad B. Doyle (1910s), Albert S. Hitchcock (1910s), Jesse More Greenman (1922), Paul C. Standley (1923-1924, 1925-1926) (Figura 2C), Carroll W. Dodge (1925, 1929-1930), Harvey E. Stork (1928), C.A. Merker (1943), William R. Barbour (1943), Elbert Luther Little Jr. (1943, 1964-1965, 1967), William A. Dayton (1943), Richard W. Holm (1949), Hugh H. Iltis (1949), Paul H. Allen (1950-1955), Robert G. Wilson (> 1958), Leslie R. Holdridge (>1949-1998), Edith Scamman (1951-1956), Philip Barry Tomlinson (1960-1970s), Richard W. Pohl (1965-1990), John T. Mickel (1967), William C. Burger (1970s, 1980s, 1990s) y Robert L. Dressler (1984, > 2005). En algunos casos no fue posible determinar con exactitud los años de su estadía en el país; cuando se consigna un decenio en plural, significa que estuvo una o más veces en ese intervalo.

Además en el campo faunístico, arribaron los zoólogos generales Alexander Emanuel Agassiz, Charles H. Towsend (1891) y Edmund Heller (1899); los entomólogos Robert E. Snodgrass (1899), Lawrence Bruner (1902), Meritt Cary (1902), J.C. Crawford (1903), James A.G. Rehn 
Revista Herencia, Vol. 35 (1), enero-junio, 2022.

(1905, 1914), William Schaus y John T. Barnes (1907-1909), al igual que los esposos Philip y Amelia Calvert (1910) (Figura 2D); el ictiólogo Seth Eugene Meek (1912); los herpetólogos Emmett R. Dunn (1920, 1929, 1936), Edward H. Taylor (1947, 1951, 1952, 1954), Archie F. Carr Jr. (1954-1956, 1957-1972), William E. Duellman (1961) y Linda Trueb (1961); el mastozoólogo y ornitólogo George K. Cherrie (1889-1894); los ornitólogos Charles C. Nutting (1882), Charles W. Richmond (1893), Melbourne Amstrong Carriker Jr. (1902-1907), Robert Ridgway (1904-1905, 1908), Austin Paul Smith (1920-1948) y Paul Slud (1950-1962); y el mastozoólogo Eugene Raymond Hall (1947). De ellos, Smith también recolectó plantas.

Cabe acotar que en marzo de 1930 vino por cuatro meses una misión austríaca, conformada por nueve personas, la cual incluía botánicos y zoólogos. Ellos fueron el botánico Georg Cufodontis, el entomólogo y aracnólogo Eduard Reimoser, el herpetólogo Rudolf Zimara, los ornitólogos Otto Porsch, Moriz Sassi y W. Moller, Otto Koller -interesado en peces y mamíferos_-, el taxidermista Alfred Stadler y el fotógrafo F. Jarkowsky.

A esta lista de naturalistas deben adicionarse personas que, sin tener formación en botánica o zoología, también recolectaron especímenes en nuestro territorio. Entre ellos destacan el guatemalteco Enrique Arcé (1863-1871) y el inglés H. Rogers, quienes trabajaron para el proyecto de la obra Biologia Centrali-Americana, a la cual se aludirá después. Además, el salvadoreño David J. Guzmán Martorell, a quien nuestro gobierno le encargó la recolección de muestras vegetales, animales y minerales para la Exposición Universal de Chicago, realizada en 1893; sin embargo, por ser médico y antropólogo, sus aportes botánicos fueron muy limitados y hasta erróneos, en varios casos.

Asimismo, hicieron recolecciones de plantas, animales, o ambos, el tipógrafo austríaco Carl Scherzer (1853); los alemanes Moritz Wagner (1853), Felipe Valentini (1854-1872), Franz Ellendorf (1854-1855), Eduard Sell Modes (1861-1893), Karl von Seebach (1864-1865), Teodoro Koschny (1869-1925), Bernardo A. Thiel (1878-1901), Karl T. Sapper (1899), Emilio Span (1921-1939) y Teodoro Assman (1935-1952), químico, etnógrafo, médico, horticultor, geólogo, finquero, sacerdote, geólogo, pintor y comerciante, respectivamente; los estadounidenses John M. Dow (1854-1894), Charles N. Riotte (1861-1867), Charles Van Patten (1872-1876) y William M. Gabb (1873-1875), capitán marino, diplomático, dentista y geólogo, respectivamente; el diplomático inglés Percy G. Harrison (1884) y el jardinero suizo Rodolfo Richard Pfau (>1890).

Es pertinente indicar que casi todos ellos publicaron sus hallazgos en revistas científicas, así como en monografías y otro tipo de documentos, al igual que en libros, a los que se aludirá en detalle posteriormente.

Para concluir esta sección, aunque hasta aquí se ha aludido especialmente a los inventarios de especies, ya en el siglo XX también se pudo avanzar bastante en la caracterización de nuestros ecosistemas. De hecho, fue justamente en Costa Rica donde el reputado dasónomo y ecólogo Leslie R. Holdridge concibió el concepto de zonas de vida - hoy aceptado mundialmente-, y lo plasmó en un valioso mapa (Tosi, 1969; Holdridge 1978), que ha servido como modelo para otros países tropicales. Dicho mapa es, a su vez, una especie de matriz, de la que se han derivado los llamados ecomapas, muy útiles para la planificación del 
Revista Herencia, Vol. 35 (1), enero-junio, 2022.

uso del suelo en regiones particulares de un país; de hecho, ya se han publicado incluso libros sobre algunas de estas regiones en Costa Rica (Acevedo et al., 2002; Kapelle et al., 2002).

Asimismo, se cuenta con dos excelentes libros - ya convertidos en clásicos-, en los que se recopila y sintetiza el conocimiento de la flora, la fauna y los ecosistemas del país (Janzen, 1983; Kapelle, 2016), así como uno focalizado en los páramos del país (Kapelle y Horn, 2005).

\section{La paz como una condición para hacer ciencia}

\section{Un territorio lejano y pobre en recursos}

Debido a la forma en que ocurrió la ocupación del territorio americano de parte de los españoles, y en particular el de Mesoamérica, Costa Rica resultó marginada desde los albores de la conquista. En efecto, la presencia de etnias indígenas mesoamericanas como los olmecas, los mayas y los aztecas, con un notable desarrollo cultural y una densidad poblacional comparativamente alta - es decir, abundante mano de obra explotable por los españoles-, así como las grandes riquezas mineras y agrícolas, propició que México y Guatemala fueran el polo principal del proceso de dominación en la región.

Dado que el territorio de Costa Rica carecía de ambos atributos, y estaba alejado, por ocupar el extremo sur de Mesoamérica, no fue de mayor interés para la Corona Española. No obstante, este abandono o aparente maldición político-geográfica, con el transcurso del tiempo se convertiría en una bendición, irónicamente, pues nos libraría de los crónicos y graves conflictos políticos y militares que han tenido que padecer nuestros vecinos centroamericanos a lo largo de la historia.

Por el contrario, en vez de riquezas mineras, fue más bien un recurso agrícola exótico lo que dinamizaría nuestra economía. En efecto, el arbusto del café, originario de África, se aclimató y adaptó con facilidad a varios microclimas locales, y desde el decenio de 1830, gracias a su exportación a Europa, se convirtió en un factor determinante del desarrollo de Costa Rica, así como en un elemento potenciador y distribuidor de riqueza (Jiménez 2013). Es decir, casi desde los albores de la independencia de España, los gobernantes del país tuvieron la visión de impulsar con decisión el cultivo y la comercialización de dicho arbusto como fuente de divisas, así como de bienestar social y económico.

Aunque es cierto que durante la colonia en el país hubo encomiendas y repartos de indígenas, así como otras formas de dominación económica y social, en Costa Rica no se alcanzó el grado de concentración de poder y acumulación de riquezas, ni tampoco las agudas pugnas políticas y la polarización social observadas en países vecinos.

Esta situación quedó bien retratada en sendos testimonios de cronistas europeos, que recorrieron el país a mediados del siglo XIX. Por ejemplo, el botánico alemán Helmuth Polakowsky acotó en 1876 que en Costa Rica "todo el mundo trabaja. El trabajo no es ninguna vergüenza. Los mismos campesinos ricos trabajan con el machete en la mano, junto con sus jornaleros" (Polakowsky, 1940). Asimismo, el viajero irlandés Thomas F. Meagher 
Revista Herencia, Vol. 35 (1), enero-junio, 2022.

comentaba en 1857 que "cada cual está en sus quehaceres; ninguno hay ocioso; nadie es demasiado presumido para no comerciar o no trabajar; a todos anima un espíritu de emancipación que tiende a alcanzar una vida independiente; el mecanismo del gobierno marcha con firmeza y, para sus fines de orden, con buen éxito proporcionado" (Meagher, 2002).

Además, aunque en la época republicana hubo clases sociales bien definidas, así como ejército —inexistente hoy, desde su abolición en 1948 - no ha habido castas militares poderosas en términos políticos y económicos. Dichas castas, en connivencia con ciertas élites de poder, han impuesto regímenes castrenses que, además de parasitarios para el erario nacional, una y otra vez han causado represión y muerte ante la disensión política, como ha sucedido en otros países, históricamente.

Es decir, salvo algunas excepciones, a lo largo de la historia, Costa Rica ha sido reconocida por su modo de vida civilista, fundado en el diálogo y la negociación. Por ejemplo, en su paso por el país en 1853, los viajeros Moritz Wagner y Carl Scherzer, alemán el primero y austríaco el segundo, recalcaban "la tranquilidad política de que gozaba", y afirmaban de manera categórica que "Costa Rica [era], la más tranquila y feliz de todas las Repúblicas de la América hispánica y una de las más hermosas y privilegiadas tierras del mundo" (Wagner y Scherzer, 1974). De hecho, su libro La República de Costa Rica en Centro América, escrito por iniciativa propia y publicado en 1856, representó un excelente acicate para que muchos europeos vinieran y se instalaran en nuestro país. Y los naturalistas no fueron la excepción.

En el caso del danés Oersted, en 1846 se había trasladado de las islas Vírgenes y Jamaica hacia Nicaragua - como se narró en páginas previas - , donde había mucho por explorar, pero no permaneció ahí, sino que poco después se mudó a Costa Rica, donde residió por año y medio. Esta importante decisión debe haber estado fundada en una razón de peso, quizás relacionada con la estabilidad política de nuestro país. En ese tiempo, después del breve pero convulso gobierno del general hondureño Francisco Morazán Quesada — quien derrocó a Braulio Carrillo Colina-, la situación política de Costa Rica se normalizó, gracias a los esfuerzos del gobernante José María Alfaro Zamora. Sin embargo, en Nicaragua, solo en 1845 —año de llegada de Oersted al Caribe - hubo cuatro presidentes, de los cuales el que más duró fue José León Sandoval, de abril de 1845 a marzo de 1847, pero en medio de grandes turbulencias.

\section{Un entorno de paz para el quehacer científico}

Para comenzar, cabe destacar que pocos años después de Oersted, los naturalistas que arribaron fueron los alemanes Hoffmann y von Frantzius, estimulados por explorar la naturaleza tropical, pero también por buscar un entorno de paz (Figura 3A), pues ambos habían vivido en carne propia la persecución política posterior a la ya citada Revolución de 1848. Y en Costa Rica no solo hallaron la tranquilidad que anhelaban, sino que incluso muy pronto incluso se hicieron amigos del presidente Juan Rafael (Juanito) Mora Porras. 
Revista Herencia, Vol. 35 (1), enero-junio, 2022.

Figura 3. Vista de San José a mediados del siglo XIX (A), así como del frontispicio de la Universidad de Santo Tomás (B).
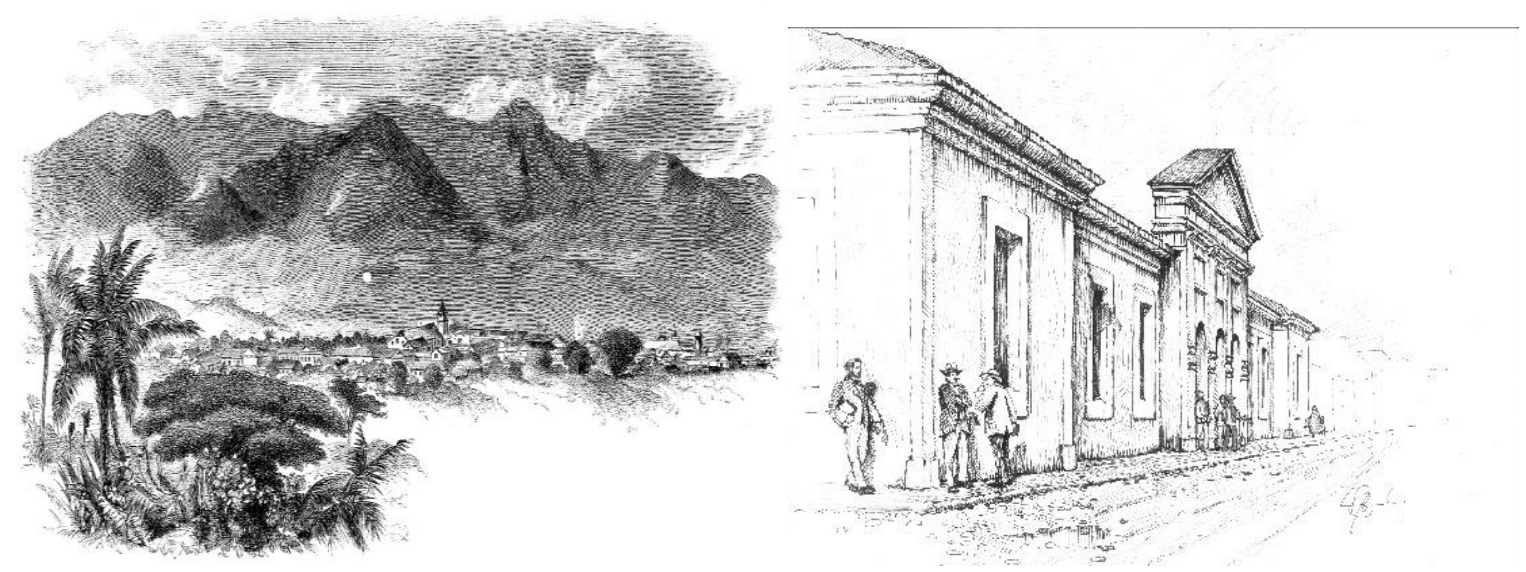

Aunque no les pudo dar un trabajo en la Universidad de Santo Tomás (Figura 3B), como lo solicitaba el egregio naturalista Alexander von Humboldt en una carta de recomendación dirigida a él, les ayudó de otras maneras. En efecto, a von Frantzius lo nombró médico de pueblo en Alajuela, con muy buen salario, mientras que - al sobrevenir en 1856 la guerra contra el ejército filibustero liderado por el esclavista William Walker- a Hoffmann lo designó Cirujano Mayor del Ejército Expedicionario. Aunque Hoffmann desempeñó con creces su función tanto en la célebre batalla de Rivas, en Nicaragua, como ante la subsecuente epidemia del cólera morbus, tres años después murió, víctima de una enfermedad degenerativa; cuando su salud empeoró, al punto de no poder ejercer su profesión, don Juanito le gestionó una pensión vitalicia, de la cual pudo disfrutar apenas unos pocos meses.

A propósito de Walker, cabe hacer una digresión aquí para indicar que, al referirse a Rivas de Pérez Zeledón - localidad donde él vivió por un tiempo-, el naturalista estadounidense Alexander F. Skutch acotaba que, al parecer, ese topónimo se deriva de la ciudad nicaragüense donde se combatió y venció a dicho jefe filibustero, y concluía su argumentación con la siguiente frase: “Feliz la nación que no pueda recordar ninguna guerra más sangrienta!" (Skutch, 2001). Es decir, reafirmaba el ambiente de paz que siempre se ha disfrutado en Costa Rica, y que a él — que había residido en Guatemala - le permitió edificar su extraordinaria obra como ornitólogo y filósofo, sin impedimento político-militar alguno.

Ahora bien, además del inusitado episodio bélico que representó la Campaña Nacional de 18561857 contra Walker — el cual marcó la vida del país para siempre_-, así como del cuartelazo de los jefes militares Máximo Blanco Rodríguez y Lorenzo Salazar Alvarado, que provocó el derrocamiento de don Juanito Mora en 1859, después sobrevendrían otros golpes de Estado, pero sin que el ejército tomara y se mantuviera en el poder, como ocurrió en todos nuestros vecinos centroamericanos hasta tiempos recientes. De hecho, ambos militares fueron removidos en 1869 mediante sendas misivas de Eusebio Figueroa Oreamuno, secretario de Guerra durante el gobierno de Jesús Jiménez Zamora. 
Revista Herencia, Vol. 35 (1), enero-junio, 2022.

De esta manera, persistió un régimen republicano - fundado en que el pueblo, como soberano, delega el poder en sus representantes, mediante elecciones libres - y de civilidad, al igual que respetuoso del derecho de asilo para los extranjeros perseguidos por motivos políticos, el cual ha prevalecido hasta hoy. Solo ha habido tres excepciones. Las primeras dos fueron los golpes de Estado de Tomás Guardia Gutiérrez en 1870, y de Joaquín Tinoco Granados, en 1917, para instalar a su hermano Federico e iniciar una oprobiosa dictadura; ésta no duró más que dos años, porque el pueblo se sublevó. En el primer caso, por ser de convicciones liberales y anti-clericales, Guardia más bien favoreció el desarrollo de la ciencia y la técnica, y fue así como arribó al país el ya citado botánico alemán Polakowsky, profesor del Instituto Nacional, como se verá después. La tercera excepción corresponde a la guerra civil de 1948, pero duró apenas mes y medio, tras la cual el ejército fue abolido.

En síntesis, a lo largo de su historia, Costa Rica ha sabido cultivar la paz como una forma de vida, pues ella es un derecho humano, así como una condición elemental para la convivencia entre los seres humanos. Pero, además, es un requisito o condición para hacer ciencia. En tal sentido, los naturalistas que han estado en Costa Rica desde hace casi dos siglos - ya sea como recolectores itinerantes o como residentes-, han podido efectuar sus labores de recolección, escritura y pensamiento con absoluta tranquilidad, sin temor a la arbitrariedad o la barbarie militar.

A su vez, a la luz de los argumentos recién citados, bien se puede afirmar que la paz paga, pues Costa Rica ha obtenido importantes réditos en varios ámbitos, por ser un país pacífico y civilista.

En el campo de las ciencias biológicas y áreas afines, de no ser por ese atributo, muy difícilmente se habrían establecido o surgido entidades como el Centro Agronómico Tropical de Investigación y Enseñanza (CATIE), el Instituto Interamericano de Cooperación para la Agricultura (IICA), la Organización de Estudios Tropicales (OET), el Centro Científico Tropical (CCT), la Universidad para la Paz (UPAZ) y la Universidad EARTH. Asimismo, tampoco se hubieran afincado en el país prominentes científicos como Ferdinand Nevermann, Alexander Skutch, Alexander Bierig, Leslie Holdridge, Joseph Tosi, Gerardo Budowski y Daniel Janzen —a quienes se aludirá posteriormente-, ni los esposos conservacionistas europeos Olof y Karen Wessberg, fundadores de Cabo Blanco, la primera área protegida del país (Figuras 4A-D). 
Revista Herencia, Vol. 35 (1), enero-junio, 2022.

Figura 4. Algunos naturalistas o científicos establecidos en Costa Rica por muchos años: Skutch (A), Holdridge (B), Budowski (C) y Janzen (D).
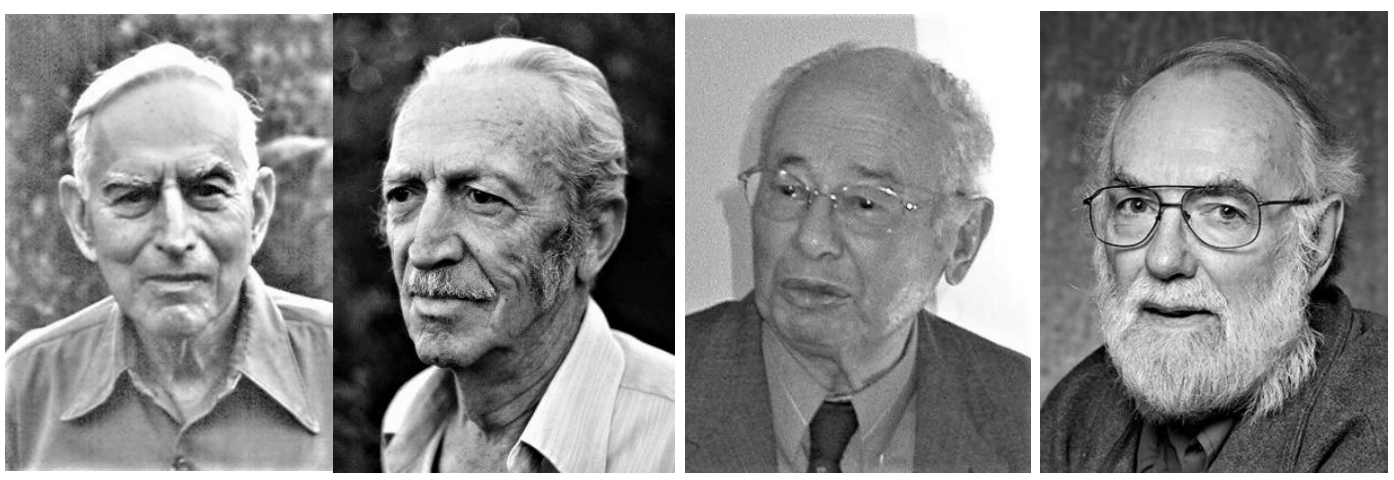

\section{Reconocimiento y aceptación de las ciencias biológicas en nuestra cultura}

\section{La visión utilitaria de las ciencias}

Para comenzar, es pertinente indicar que, en el caso de las ciencias exactas (matemática, física y química), se cultivaron desde la época colonial, por razones obvias, a partir del conocimiento acumulado en Europa y Asia. Por ejemplo, la matemática era imprescindible para las transacciones comerciales. En cuanto a la física, algunas de sus aplicaciones prácticas, como la ingeniería, eran esenciales para la navegación marítima, la construcción de acueductos y edificios, al igual que lo era la agrimensura para la medición de tierras baldías, tan abundantes entonces. Finalmente, la química era de gran pertinencia en la mineralogía y la acuñación de monedas, así como en la farmacognosia — basada en principios activos obtenidos de organismos vivientes - y la farmacología.

Nótese que dichas ciencias y sus ramas técnicas tenían un carácter utilitario, es decir, se fomentaban sobre todo debido a su aplicabilidad o utilidad para resolver problemas de la sociedad. En tal sentido, en relación con las ciencias biológicas, la botánica avanzó sobre todo por su conexión con la agricultura y la farmacología, en tanto que la zoología lo hizo por su asociación con la medicina (anatomía y patología humanas). Esta tendencia sería tan determinante y perdurable en nuestra historia, que las primeras dos entidades educativas fundadas en Costa Rica en relación con las ciencias biológicas, fueron las escuelas de Farmacia y Agricultura, que incluso antecedieron a la Universidad de Costa Rica.

Una evidencia fehaciente del carácter utilitario de la biota tropical fueron las ya citadas grandes expediciones a América organizadas por el Imperio Español, lideradas por médicos, botánicos o farmacéuticos, quienes estaban fuertemente influidos por los relatos de los cronistas que los antecedieron. En el caso de Mesoamérica y el Caribe - incluyendo una parte de Costa Rica - el cronista Gonzalo Fernández de Oviedo (1992) enumeró y se refirió con amplitud a numerosas especies de flora y fauna de uso cotidiano como fuente de alimentos, bebidas, medicinas, toxinas, tintes, fibras, vestido, vivienda, armas para cazar y pescar, ornamentos, rituales religiosos, etc. Varias de las especies de plantas habían sido domesticadas y mejoradas por las etnias indígenas, tras siglos de cuidadosa experimentación empírica, y 
Revista Herencia, Vol. 35 (1), enero-junio, 2022.

resultaban de gran interés para los nuevos exploradores, dado que ellos estaban asociados con jardines botánicos, en los que se priorizaba la recolección y registro de dichas especies vegetales.

De las dos expediciones que se concentraron en México - entre cuyos integrantes figuraban excelentes artistas, para dibujar las especies halladas-, aunque su foco de interés fue dicho país, la segunda extendió sus recolecciones un poco más al sur, de lo cual se benefició Costa Rica. Además, por fortuna, los exploradores no se limitaron a recoger plantas, sino que también recolectaron y dibujaron animales, para legarnos una muy rica colección de imágenes de la biota mesoamericana. Lamentablemente, eso sí, el acervo pictórico de ambas expediciones estuvo signado por la tragedia, y en gran medida se malograría.

En el caso de la primera expedición, resultaron nada menos que 38 volúmenes de ilustraciones, pero debido al elevado costo de publicarla, el rey Felipe II aceptó publicar apenas una versión resumida, la cual apareció medio siglo después. Aunque los materiales originales permanecieron en la biblioteca de El Escorial, se quemaron en un incendio ocurrido en 1671, desgraciadamente.

En el segundo caso, Sessé murió cinco años después de retornar a España, mientras que Mociño debió exiliarse en Francia posteriormente, llevando consigo parte de los materiales; en 1820 regresó a Barcelona, ya enfermo, donde murió. Aunque en 1885 se publicaron en México las obras Flora Mexicana y Plantae Novae Hispaniae (Plantas de Nueva España), carecían de las correspondientes ilustraciones. Por fortuna, aunque se ignora cómo llegaron éstas a manos de la familia catalana Torner, en 1981 ellos las vendieron al Instituto Hunt de Documentación Botánica, en Pittsburgh, EE.UU., donde hoy se conservan. Este tesoro científico consiste en unas 2000 láminas esbozadas o en colores (Figuras 5A-B), de las cuales unas 1800 corresponden a plantas, y el resto a insectos, crustáceos, peces, reptiles, aves y mamíferos. 
Revista Herencia, Vol. 35 (1), enero-junio, 2022.

Figura 5. Ejemplos de los dibujos de la citada expedición: Amaryllis formosissima (A) y Sparus gibbus (B), hoy denominadas Sprekelia formosissima y Calamus bajonado, respectivamente.

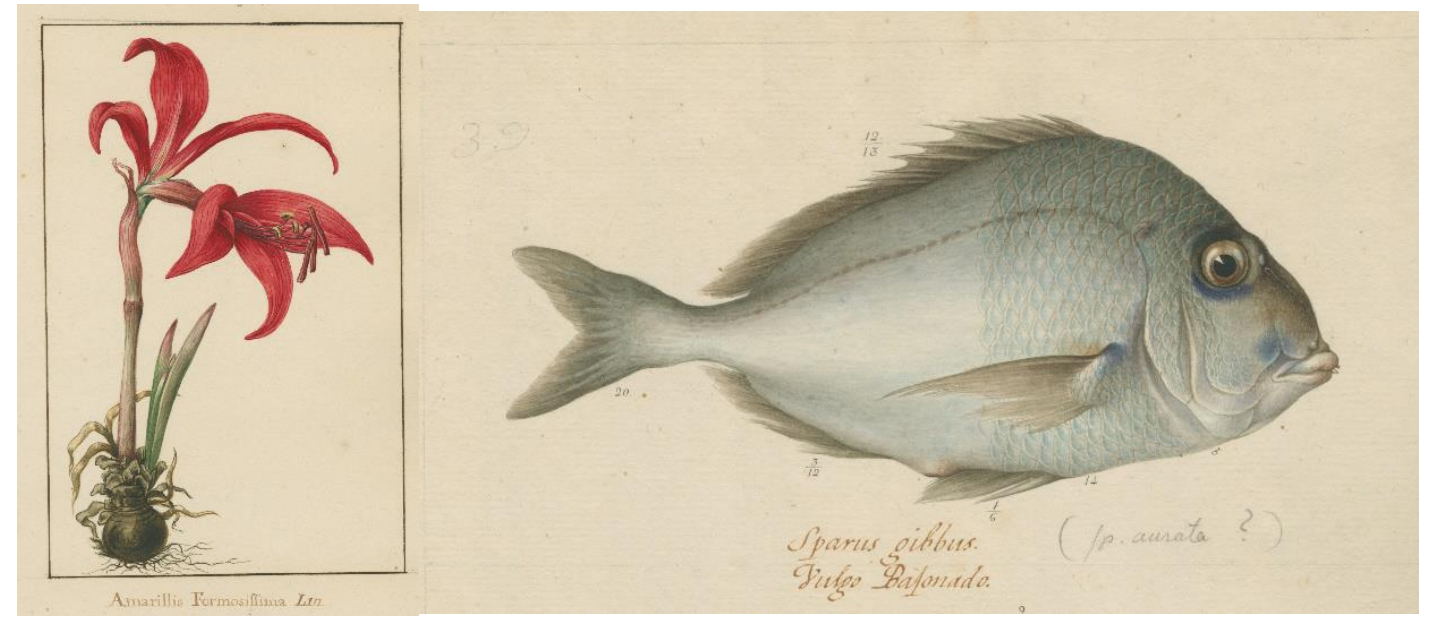

Es de suponer que, si estas vicisitudes históricas no hubieran ocurrido, y las obras se hubieran publicado de manera oportuna y como lo ameritaban tan ingentes esfuerzos de exploración científica, esto hubiera estimulado fuertemente el desarrollo de las ciencias biológicas en Costa Rica. Al respecto, hoy que hemos podido consultarlas y apreciarlas por vía electrónica, tenemos la certeza de que - al estar disponibles en la biblioteca de la Universidad de Santo Tomás-, el solo hecho de observar la calidad científica y artística de las citadas imágenes, hubiera sido un acicate suficiente para motivar a jóvenes promisorios, que se habrían convertido en nuestros primeros naturalistas. Asimismo, hubiera representado un extraordinario punto de partida para, a partir de esas ilustraciones y sus respectivos nombres científicos, que se empezara a inventariar la flora y la fauna del país.

Ahora bien, a pesar de tan sensible e irremediable vacío, es posible que los conocimientos acerca de la flora y la fauna tropicales no estuvieran ausentes en nuestro medio, gracias a las clases más adineradas y cultas, que tenían interés en estas materias y podían adquirir libros en el extranjero directamente, o encargarlos en algunas librerías locales que importaban libros y periódicos franceses, ingleses y españoles. Igualmente, aunque la biblioteca de la Universidad de Santo Tomás era deficitaria, contenía algunos libros valiosos en el ramo. Por ejemplo, en febrero de 1845 se anunció por la prensa que había adquirido cinco de los 30 volúmenes de la monumental obra Viaje a las regiones equinocciales del Nuevo Continente, de Humboldt; cabe acotar que el primero de los 30 volúmenes fue publicado en 1807 y traducido al español en 1826, de modo que esta versión llegó al país con 19 años de retraso. Nótese que ello ocurrió casi dos años antes del arribo del naturalista Oersted.

\section{La semilla que el danés Oersted sembró}

Es pertinente indicar que siete años antes, nuestra sociedad había atestiguado la presencia del ya también citado diplomático y botánico austríaco Emanuel Ritter von Friedrichsthal. En efecto, a mediados de 1839 él compareció ante el gobierno del jefe de Estado Braulio Carrillo Colina, para solicitar su ayuda en el acopio de información acerca de algunos de nuestros recursos naturales. Aunque él no se presentó como naturalista ni científico, sino como 
Revista Herencia, Vol. 35 (1), enero-junio, 2022.

emisario de su gobierno, se le vio recolectando plantas en varias localidades de San José, Alajuela, Heredia, Cartago y Guanacaste. A pesar de que permaneció aquí pocas semanas, von Friedrichsthal fue el primer naturalista que visitó nuestro territorio.

Cabe suponer que, ya que el quehacer científico era algo totalmente ajeno a nuestras cultura y cotidianidad, al verlo con abundantes muestras de plantas, más un barómetro - para medir altitudes, que en aquella época eran inmensos y debían transportarse en mula-, la gente lo considerara un excéntrico. Es lógico suponer que siete años después — ya lejos de la fugaz estela dejada por von Friedrichsthal—, con la llegada de Oersted, quien vivió año y medio en el país, estas escenas se multiplicaron y se tornaron comunes. Por su prolongada y fructífera estadía, no hay duda de que fue el primer naturalista residente en Costa Rica, así como el primero en explorar a fondo su naturaleza.

De hecho, Oersted recorrió gran parte del territorio nacional, lo que incluyó el ascenso de los volcanes Irazú, Poás y Barva, al igual que la navegación hasta la isla San Lucas, donde recolectó entre 600 y 700 especies de plantas y fauna marina, muchas de las cuales fueron nuevas para la ciencia. Asimismo, trazó un mapa del Valle Central, así como un detallado dibujo y un perfil de las cordilleras que lo rodean. Además, por si no bastara con todo esto, por siete meses registró la temperatura y la precipitación en San José, que fueron los primeros datos climáticos tomados en el país. Toda esta información quedó recogida en 43 artículos científicos, más el libro L'Amerique Centrale.

No obstante, aparte de sus aportes propiamente científicos, hay un elemento clave, que conviene destacar. En efecto, Oersted cultivó amistad con dos notables personalidades, Francisco María Oreamuno Bonilla y Francisco de Paula Gutiérrez Peñamonge. Este último era hermano de la esposa de Oreamuno, además de que otra hermana suya estaba casada con José Joaquín Mora Porras - hermano de don Juanito_- a la vez que su hermano Manuel Joaquín con Rosa Mora Porras, hermana de éstos. Es decir, Oersted tuvo la oportunidad de alternar con miembros de los círculos de mayor poder económico y político, y como resultado de esa interacción, ellos comprendieron mejor el valor del conocimiento científico para la sociedad. Es decir, quizás sin proponérselo, Oersted había logrado que a la ciencia se le otorgara carta de ciudadanía en nuestra sociedad y nuestra cultura.

Esto podría explicar, al menos en parte, el interés de don Juanito por fundar un museo y un jardín botánico en la capital, a lo cual se aludirá posteriormente. Esto ocurrió en 1850, dos años después de la partida de Oersted.

Asimismo, en años posteriores hubo dos expresiones inequívocas de la importancia concedida a las ciencias biológicas en el país, y en ambas estuvo involucrado el diplomático Ezequiel Gutiérrez Iglesias (Figura 6A), hijo del recién citado Francisco de Paula Gutiérrez. Dado que él tenía siete años de edad cuando Oersted partió de Costa Rica, posiblemente recordaba al botánico danés, además de que en su casa quizás se hablaba de él en los años subsiguientes, de modo que valoraban la importancia de las labores que realizaba un naturalista. Además, Oersted dedicó a su padre la especie Siphocampylus (hoy Centropogon) gutierrezii (Figura 6B), de la familia Campanulaceae, un gesto que, de seguro, la familia agradecía y recordaba. 
Figura 6. Gutiérrez (A) y la planta Centropogon gutierrezii (B).

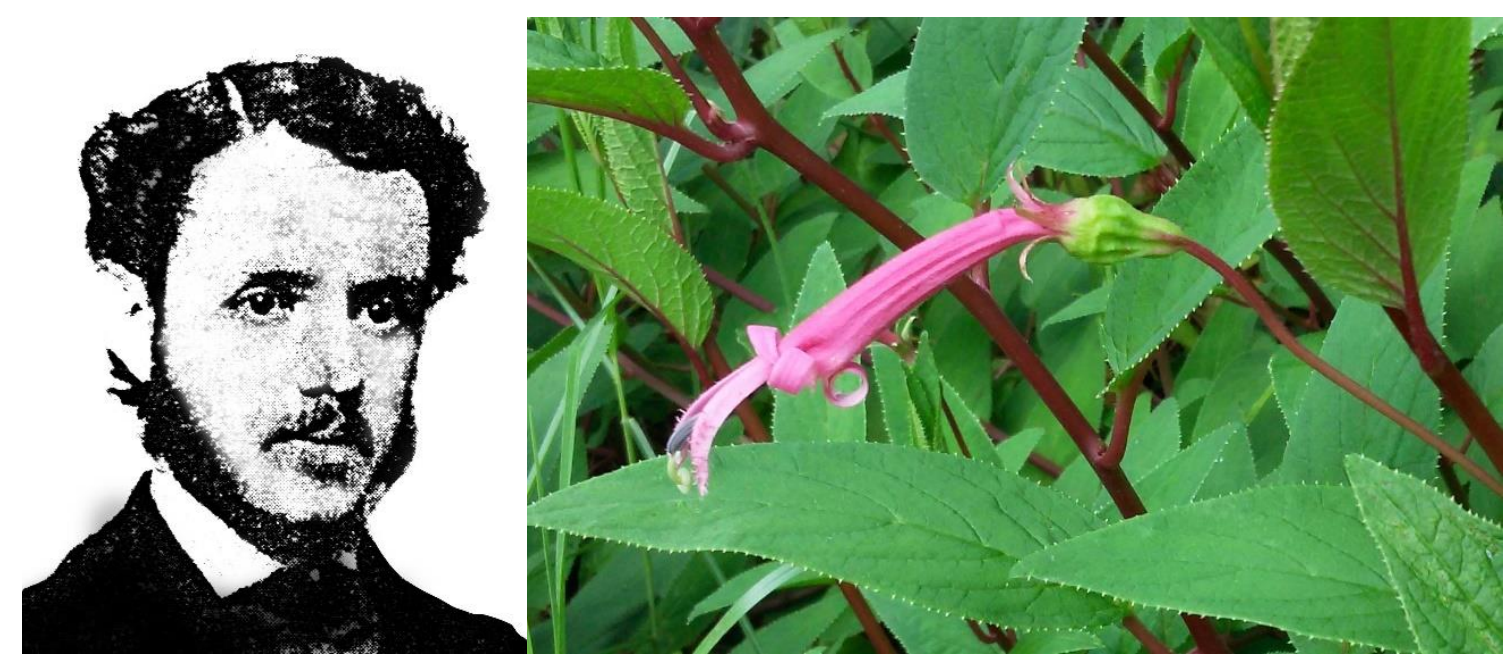

En el primer caso, durante la segunda administración de José María Castro Madriz, a mediados de 1866 se planteó un proyecto para construir en seis años un ferrocarril interoceánico. Su planeamiento estuvo a cargo del ingeniero alemán Francisco Kurtze, quien viajó a Nueva York como emisario del gobierno, donde se logró firmar un contrato con la empresa Costa Rica Railroad Company, dirigida por el general John Charles Fremont. Sería financiado en montos equivalentes por las dos contrapartes.

Fue en esta coyuntura cuando alguien en nuestro gobierno tuvo la extraordinaria idea de efectuar una gran expedición científica entre los puertos de Limón y Caldera. Sospechamos que el artífice de esta iniciativa fue Gutiérrez Iglesias - encargado de negocios en Washington-, quien incluso contactó a Spencer F. Baird, subdirector del Instituto Smithsoniano, en dicha ciudad, para que elaborara una propuesta. Ellos sugerían que el alemán von Frantzius fuera el coordinador general y el zoólogo de la expedición, y que se le sumaran un botánico y un geólogo estadounidenses. El monto de la propuesta ascendía a US\$ 30.000, a los que debían sumarse US\$ 10.500, para hacer un tiraje de 250 ejemplares de un libro, con ilustraciones de muy alta calidad. Aunque nuestro Congreso ya había aprobado el proyecto de ferrocarril, poco después se supo que, lamentablemente, Fremont y sus socios eran unos embusteros, quienes carecían del dinero que decían tener para acometer la obra.

En el segundo caso, durante el gobierno del general Tomás Guardia, en 1871 se propuso construir un ferrocarril entre el Valle Central y la costa del Caribe, para lo cual suscribió un contrato con el estadounidense Henry Meiggs, aunque poco después el proyecto quedó en manos de su sobrino Minor C. Keith. Además de incursionar en la siembra de banano, Keith deseaba hacer prospecciones para explotar oro en la región de Talamanca, para lo cual su hermano Henry Keith contactó el reputado geólogo William M. Gabb. Sin embargo, el Congreso rechazó su proyecto, por considerarlo colonialista, y entonces Keith lo descartó y traspasó al gobierno su contrato con Gabb.

A partir de ese momento, el diplomático Gutiérrez Iglesias consideró importante y oportuno aprovechar la expedición geológica prevista, para complementarla con una de carácter 
Revista Herencia, Vol. 35 (1), enero-junio, 2022.

biológico; al parecer, para entonces no residía en Washington (Quirós, 2013). Por tanto, de inmediato contactó al joven José Cástulo Zeledón Porras — nuestro primer naturalista-, quien desde 1868 realizaba una pasantía en el Instituto Smithsoniano. Fue así como a inicios de 1873 comenzó la exploración de Talamanca, con Gabb como coordinador, geólogo y zoólogo — sin ser biólogo-, y con Zeledón como ornitólogo. En realidad, aunque unos dos años después Gabb concluyó la expedición, no tuvo el éxito esperado, en parte por problemas con sus ayudantes; de hecho, Zeledón la abandonó casi empezando, debido a confrontaciones con Gabb, y víctima de la malaria.

En todo caso, más allá de los débiles logros de ambas tentativas de exploración, lo más importante es que en nuestra sociedad ya se reconocía la importancia de las ciencias naturales, y de las ciencias biológicas en particular. Y sería así como, a partir de entonces, con el ir y venir de tantos naturalistas recorriendo nuestro territorio en sus labores de recolección, sumado al hecho de que varios de ellos establecieron familia en Costa Rica, ante los ojos del común de la gente se fue legitimando la recolección y el estudio de las plantas y los animales como parte de la actividad científica y la cultura del país.

\section{La visión y la necesidad de nutrirse del conocimiento científico extranjero}

\section{Un sistema educacional raquítico}

Para empezar, es pertinente indicar que, primero como integrante de la Capitanía General de Guatemala y, ya lograda la independencia en 1821, como miembro de la República Federal de Centro América - entre 1825 y 1838 - Costa Rica no disfrutó de verdadera autonomía política, ni de un desarrollo institucional propio, incluyendo los sectores educativo y científico. Fue en 1814 - apenas siete años antes de la independencia- cuando se fundó la Casa de Enseñanza de Santo Tomás, una especie de híbrido entre enseñanza primaria y secundaria. Antes de esta fecha, a falta de entes educacionales, los niños de las clases adineradas se instruían con tutores privados.

Para captar mejor cuál era la enseñanza recibida en dicho recinto, es oportuno señalar que, al graduarse el primer bachiller en Filosofía y Artes, Vicente Herrera Zeledón — con 17 años de edad-, en el examen final debió demostrar que era versado en las siguientes materias: historia universal, historia de la filosofía, lógica, moral, derecho natural, metafísica, física, historia natural, geometría, astronomía y principios generales de retórica. Nótese la presencia de algunas ciencias exactas (geometría, física y astronomía) y de historia natural. Aunque esta última materia posiblemente incluía geología, botánica y zoología, el examen de Herrera se restringió a los mamíferos, al especificarse que debía conocer acerca de "la primera clase de los animales vertebrados y caracteres que los distinguen de los demás animales". Es de suponer que los exámenes de otros estudiantes abarcaran temas diferentes.

Al parecer, quien enseñaba estas últimas materias era el nicaragüense Rafael Francisco Osejo, llegado al país en el propio 1814 —donde residiría hasta 1834-, contratado por el Ayuntamiento de San José (Zelaya, 1973). Recién llegado, por un corto período fue regente o rector de la Casa de Enseñanza de Santo Tomás. En realidad, él no tenía formación en 
Revista Herencia, Vol. 35 (1), enero-junio, 2022.

ciencias, por lo que sus conocimientos al respecto eran muy limitados; de hecho, recién se había graduado como bachiller en filosofía en la Universidad de León, en Nicaragua.

Como una curiosidad, en 1828 ofreció vender su biblioteca personal, que contenía 82 títulos, de los cuales había apenas tres referidos a ciencias naturales. Uno era el libro New Complete and Universal Natural History of the Most Remarkable Quadrupeds, Birds, Fishes, Reptiles, and Insects, in the Known World, escrito por Benjamin Mayo y publicado en 1818; es decir, era una especie de tratado sobre mamíferos, aves, peces, reptiles e insectos del mundo. Los otros libros en venta correspondían a los respectivos tomos de botánica e historia natural, de una colección de 12 volúmenes intitulada Memorias instructivas y curiosas sobre agricultura, comercio, industria, economía, química, botánica, historia natural, etc., publicada entre 1778 y 1791 por el compilador español Miguel Jerónimo Suárez y Núñez.

Ahora bien, ante la inexistencia de universidad en el país, donde se formarán los profesionales considerados como los más necesarios para la sociedad de entonces (abogados, médicos y sacerdotes), se debía recurrir a universidades extranjeras.

En tal sentido, aunque los muy acaudalados hermanos Mariano y José María Montealegre Fernández se formaron en Escocia, el primero como ingeniero en el Marischal College y el segundo como cirujano en la Universidad de Edimburgo, representan la gran excepción, pues la norma era que los muchachos - muy jóvenes aún- lo hicieran cerca del país. Un buen ejemplo es el del prominente político José María Castro Madriz - dos veces gobernante del país-, quien, en 1838, recién cumplidos los 20 años, se graduó de bachiller en filosofía en la Universidad de León, en Nicaragua, para en 1841 y 1842 obtener los grados de doctor en leyes y filosofía, respectivamente. En el caso de los médicos, lo hacían en dicha universidad o en la Universidad de San Carlos, en Guatemala, donde se graduaron Pablo Alvarado Bonilla, Bruno Carranza Ramírez, Cruz Alvarado Velazco, Lucas Alvarado Quesada, Andrés Sáenz Llorente y Jesús Jiménez Zamora (Arias, 2002). Por su parte, los sacerdotes se formaban en el Seminario Conciliar de León.

A partir de la independencia, conforme el país avanzó en su desarrollo, es lógico suponer que la demanda de profesionales aumentó de manera paulatina. Por fortuna, en esa época fue común que recalaran en nuestras costas personas que, ya fuera con título académico o de manera empírica, ejercían la abogacía y la medicina, al igual que otras disciplinas relevantes, como la farmacia, la ingeniería, la arquitectura o la agrimensura. Asimismo, los graduados de la Casa de Enseñanza de Santo Tomás tendrían la expectativa de formarse en algún campo profesional, pero sin salir del país, lo cual en 1843 indujo al jefe de Estado José María Alfaro Zamora a transformar dicho ente en la Universidad de Santo Tomás, financiada con los ingresos provenientes del monopolio del tabaco. En ello jugó un papel clave su secretario de Instrucción Pública, el recién citado Castro Madriz.

Con el surgimiento de esta universidad, el panorama para las ciencias biológicas no varió en absoluto. Además de que no existía investigación como actividad académica, basta una mirada al plan de estudios de entonces para captar que la oferta de carreras se limitaba a las ramas de teología, derecho, letras y filosofía. Es decir, carreras para cuya enseñanza bastaba con un pizarrón, tiza, cuadernos y libros. 
En virtud de lo anterior, aunque para 1851 Molina (2007) acotaba que en dicho ente "se estudian algunas ciencias", esto no parece cierto a primera vista, aunque podría serlo, pues dentro de la materia denominada filosofía en aquella época se incluía la matemática, más algunos fundamentos de física, química, geología, astronomía, así como la historia natural. Asimismo, en cierto momento se estableció la carrera de agrimensura, de gran pertinencia, pues el país estaba despoblado y abundaban las tierras baldías que, tras ser denunciadas, ameritaban ser medidas para su registro.

\section{Las ciencias biológicas se abren paso}

Antes de continuar, es oportuna una digresión aquí, para referirse a la materia denominada historia natural, que es la más relacionada con las ciencias biológicas.

De lo que hemos podido indagar, fue dictada por al menos seis profesores, en diferentes épocas e instituciones: el alemán Helmuth Polakowsky (Figura 7A), el catalán José de Torres Bonet (Figura 7B), el cubano José de Frías Cintra, el español Juan Fernández Ferraz, el suizo Paul Biolley, y el nacional Juan de Dios Céspedes. Casi todos ellos también impartían entre dos y cuatro materias más, entre las que se incluían matemática, física, química, dibujo topográfico, agricultura o idiomas, pero Biolley era el único que en realidad sabía de biología de campo, pues tenía formación como científico, y recolectaba, clasificaba y estudiaba sobre todo insectos y moluscos, así como otros animales y hasta plantas.

Figura 7. Polakowsky (A) y Torres Bonet (B), destacados profesores del Instituto Nacional.
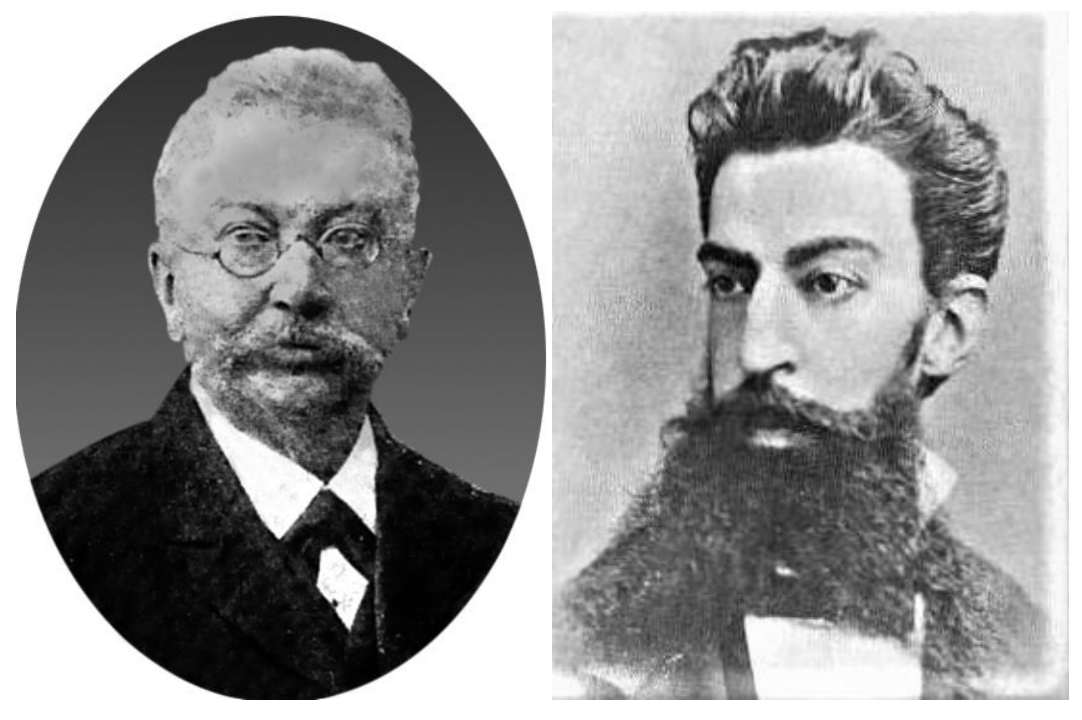

Un caso extremo fue el del citado Fernández Ferraz, quien se formó en filosofía y letras, pero daba clases de historia natural en el Colegio San Luis Gonzaga, en Cartago, e incluso fue director del Museo Nacional en 1898. En el citado colegio también impartió lecciones de clásicos griegos y latinos, estética, lengua inglesa, dibujo y teneduría de libros; más que especialista, era "todero", como era común en los profesores de aquella época. En 
Revista Herencia, Vol. 35 (1), enero-junio, 2022.

determinado momento, en 1888, Biolley lo encaró públicamente, y de manera frontal le espetó que "solamente dos años hace que esta ciencia [la Historia Natural] obtuvo carta de naturalización en Costa Rica y comenzó a figurar entre las asignaturas del programa oficial de las escuelas comunes". Además, indicó que fue únicamente en el Instituto Nacional donde "ciertamente hubo profesores de verdadera competencia, como los señores Polakowsky y Torres Bonet" (Obregón, 2006). Cabe aclarar que Biolley no conoció a estos dos, por lo que sus juicios se deben haber basado en el criterio de exalumnos de ambos.

A propósito de esta última entidad, es pertinente indicar que el Instituto Nacional fue un ente de educación secundaria fundado en 1874 - a costas del presupuesto de la Universidad de Santo Tomás, en gran medida-, durante la administración del general Tomás Guardia, y abrió sus puertas en mayo de 1875. En esos tiempos no existía educación secundaria en la capital, sino en Cartago, en el Colegio de San Luis Gonzaga, fundado en 1842, pero abierto 27 años después, en 1869.

Para entonces, es muy posible que hubiera consenso, al menos en ciertos sectores intelectuales y políticos, de que nuestro incipiente sistema educacional estaba viciado de endogamia o consanguinidad académica, que es tan contraproducente para la calidad de la enseñanza y la educación, por lo que, con gran visión, se decidió reclutar profesores de alto nivel, en Europa. De hecho, para el Colegio de San Luis Gonzaga se contrató como director al ya citado español Valeriano Fernández Ferraz, a quien acompañaron sus dos hermanos, recién mencionados.

En el caso del Instituto Nacional, la labor de reclutamiento se le encomendó al célebre diplomático Manuel María Peralta y Alfaro, quien residía en Londres, donde fungía como Encargado de Negocios de Costa Rica. Fue así como, tras una cuidadosa selección, arribaron al país el suizo Renard (Reginaldo) Thurman, el italiano Rodolfo Bertoglio, y los alemanes Gustavo Frangott Schwarz y Helmuth Polakowsky. El primero fue su director, además de que enseñaba inglés, mientras que Bertoglio impartía matemática pura y aplicada, ciencias y geografía. De los alemanes, Schwarz era profesor de historia, geografía, latín, griego y literatura moderna, en tanto que Polakowsky lo era de física, química, mineralogía, botánica y zoología. También fueron docentes algunos extranjeros residentes en el país.

Aunque, por diversos motivos y circunstancias, el proyecto académico del Instituto Nacional no alcanzó todo el éxito deseado, dejó una indeleble huella en nuestras ciencias biológicas. En primer lugar, uno de sus graduados fue el joven alajuelense Anastasio Alfaro González, nuestro segundo naturalista, pues el primero fue José Cástulo Zeledón; a él se sumaron Miguel Obregón Lizano y Luis Matamoros Sandoval, que descollarían en los campos de la geografía y la ingeniería, respectivamente.

Asimismo, aunque Polakowsky no estuvo más que un año en su puesto, su legado fue de gran relevancia para el desarrollo de nuestras ciencias biológicas. Es admirable cómo, insatisfecho con tan solo sus labores docentes de secundaria, en su tiempo libre, por iniciativa personal y con fondos propios, este auténtico científico se propuso trascender, por lo que emprendió exploraciones botánicas por varias regiones del país, al punto de sintetizar sus hallazgos en el amplio artículo La flora de Costa Rica. Contribución para el estudio de la fitogeografía 
Revista Herencia, Vol. 35 (1), enero-junio, 2022.

centroamericana. Además, publicó 26 artículos sobre nuestra naturaleza, así como sobre otras cuestiones de la vida nacional.

\section{La paradigmática reforma liberal}

Ahora bien, a pesar del aparente fracaso acontecido en el Instituto Nacional — que tuvo corta vida, pues expiró en 1887, tras varios vaivenes político-administrativos-, en 1886 sería otro gobierno liberal el que acometería una reforma sustancial de nuestro sistema educacional, e insistiría en contratar profesores europeos.

Dicha reestructuración implicó la clausura de la Universidad de Santo Tomás, en medio de una acre polémica. Aunque el artífice de este proceso, Mauro Fernández Acuña - secretario de Instrucción Pública - argumentaba que "Universidad, propiamente dicha, donde se cultive la ciencia pura, no tiene razón de ser en un país pequeño como Costa Rica”, es difícil creer que en ella se hiciera ciencia. Quizás él se refería al conocimiento teórico en general, pues en aquella época — quizás porque el término "ciencia" proviene del latín scientǐa, equivalente a "conocimiento"- se equiparaban ambos conceptos. Esto es incorrecto, pues no todo conocimiento es de naturaleza científica.

Al respecto, y en relación con la enseñanza superior, ya desde unos dos decenios antes, el naturalista alemán von Frantzius indicaba que "aquí existe una mal llamada universidad"; esto lo acotó en una carta a Spencer F. Baird. Aunque este juicio suena muy tajante y descalificador, lo cierto es que él sabía lo que era hacer ciencia de verdad, pues fue docente e investigador en las universidades de Friburg y Breslau. Incluso en esta última alternó con científicos de la talla del fisiólogo y patólogo Jan Evangelista Purkinje, el fisiólogo y laringólogo Johann Czermak, el patólogo Friedrich Theodor von Frerichs, el químico Robert Bunsen y el físico Gustav Kirchhoff, aún famosos en sus respectivos campos; los dos últimos descubrieron los elementos químicos cesio y rubidio en 1860, mediante el espectrómetro, un aparato para estudiar la luz, diseñado por ellos, y de uso aún hoy. Además, en la Universidad de Berlín fue alumno - y después colega y muy cercano amigo - del patólogo Rudolf Virchow, nada menos que proponente de la Teoría Celular.

En realidad, como adalid de las ideas liberales, la visión de Fernández era destinar el presupuesto universitario a fortalecer la educación secundaria, por lo que impulsó y concretó el establecimiento del Liceo de Costa Rica, el Colegio Superior de Señoritas, y el Instituto de Alajuela. Sin embargo, dada su importancia, a su vez se proponía conservar la Escuela de Derecho, así como crear escuelas de Medicina y Farmacia, también a nivel universitario. Además, planteaba la necesidad de fundar una Escuela Politécnica "en la cual se cultiven las ciencias, desde el punto de vista de su inmediata aplicación en la vida práctica” (Pacheco, 1972). Es decir, carreras técnicas que contribuyeran a acelerar el progreso material del país.

Como resultado de estos empeños, y dada la urgencia de implementar estas políticas, se decidió contratar profesores europeos, en lo cual, de nuevo, fue clave la labor del ya citado diplomático Peralta. No obstante, esta vez él se concentró en Suiza, donde se contrató a Paul Biolley Matthey, Ludwig Schönau - primer director del Liceo de Costa Rica - y William Phillipin, quienes arribaron a inicios de 1886. En los siguientes meses o años serían sucedidos 
por Henri Pittier Dormond, Juan Sulliger, Adolphe Tonduz Berthoud, Juan Rudín Iselin, Gustavo Louis Michaud Monnier, Paul P. Piguet, Juan Pradier, Arthur Dedie, Samuel Montandon, Estela Biolley y dos maestras de apellidos Weiskopf y Daniel.

De esta legión de educadores, todos cumplieron una importante labor, aunque pocos permanecieron en el país por el resto de sus vidas. Quienes dejaron una impronta más profunda y duradera fueron Biolley, Pittier, Tonduz, Rudín y Michaud, los tres primeros en las ciencias biológicas (Figuras 8A-C). No obstante, debe destacarse que Michaud fue una figura científica determinante como inspiración y guía para el joven Clodomiro (Clorito) Picado Twight, nuestro más preclaro científico hasta la actualidad.

Figura 8. Los tres principales naturalistas suizos: Biolley (A), Pittier (B) y Tonduz (C).
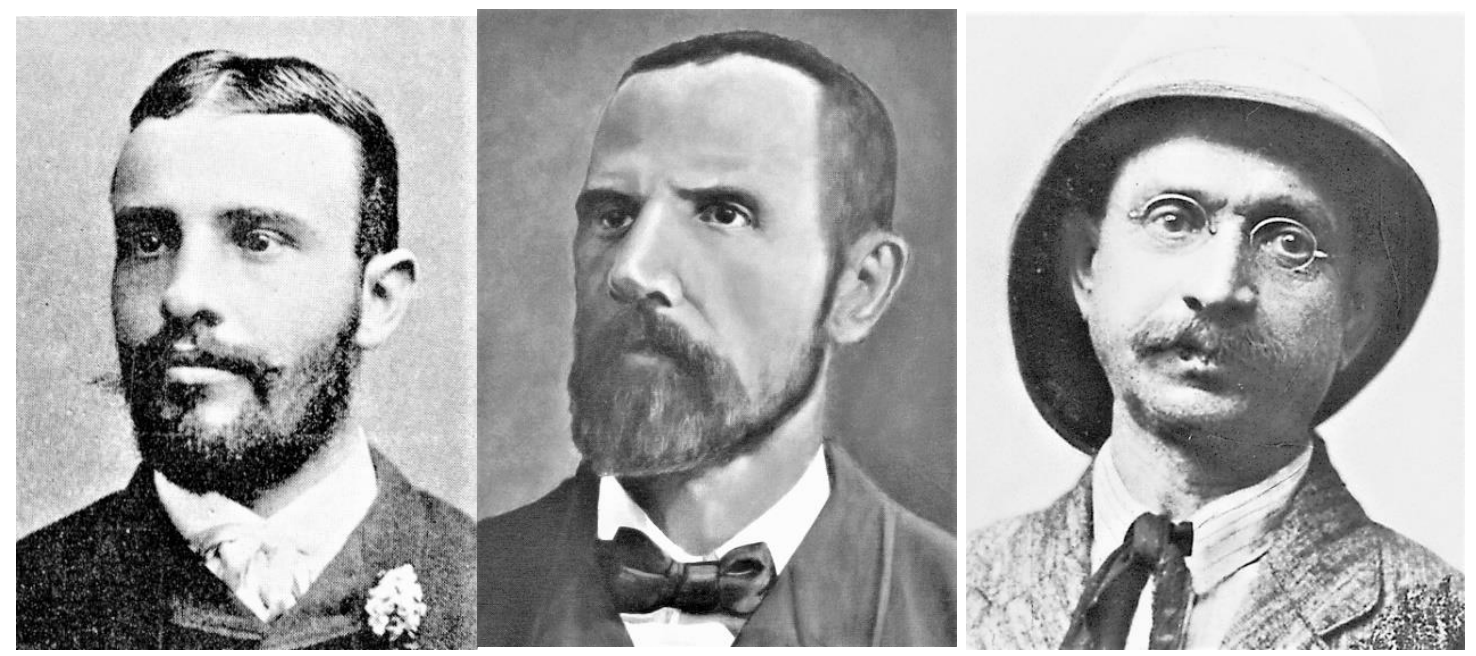

Para concluir esta sección, debe reiterarse cuán atinadas fueron las políticas estatales orientadas a reclutar científicos europeos de alto nivel, con fines de enseñanza, pero que rindieron muy altos réditos en el desarrollo de nuestras ciencias biológicas, en lo cual se profundizará posteriormente.

Ello representó un aprendizaje que resultó invaluable a lo largo de nuestra historia, que en gran medida se repetiría para la llamada Reforma de 1957 en la Universidad de Costa Rica — fundada en 1940 por el médico y presidente Rafael Ángel Calderón Guardia_-, cuando su rector Rodrigo Facio Brenes se propuso contratar profesores extranjeros de alto nivel, para enriquecer el claustro universitario. A esto se aludirá en más detalle hacia el final de este artículo.

\section{Oportunas y fecundas alianzas científicas internacionales}

\section{Las redes entre naturalistas y taxónomos}

La colaboración entre investigadores siempre ha sido una norma en el mundo de la ciencia. Quizás el mejor ejemplo es el del célebre taxónomo Carlos Linneo, quien en el siglo XVIII pudo describir y bautizar innumerables especies de plantas y animales de casi todo el mundo, 
Revista Herencia, Vol. 35 (1), enero-junio, 2022.

sin tener que desplazarse mucho de su natal Suecia, gracias a que recibía especímenes de quienes necesitaban que él se los identificara. En realidad, no es posible imaginar el desarrollo actual de las ciencias biológicas en el mundo - y de las ciencias en general-, sin la existencia de redes de colaboradores.

En el caso de Costa Rica, desde los pioneros von Friedrichsthal y Oersted - que eran naturalistas, pero no taxónomos - hasta hoy, todos los biólogos que hemos realizado investigación de campo necesitamos recurrir a especialistas para que nos identifiquen especies de plantas o animales desconocidas. Esto por lo general lo hacen sin costo económico alguno, pues se trata de un pacto tácito, como resultado del cual ellos a la vez se benefician, pues se ahorran los ingentes esfuerzos y costos implicados en la recolección, la preparación y el envío de especímenes.

En tal sentido, un hecho fehaciente es que cuando Hoffmann y von Frantzius partieron hacia Costa Rica, en la revista Bonplandia -órgano oficial de la Academia Leopoldina o Academia Alemana de Ciencias-, se indicaba que "notables científicos de primer nivel, entre los que nos limitaremos a nombrar en Alemania a Johannes Müller, [Martin] Lichtenstein, [Johann Friedrich] Klotzsch, [Julius] Ratzeburg y [Carl] von Siebold, en Inglaterra a [John] Gould y a [Joseph George] Cumming, en Rusia a [Karl] von Baer y a [Johann Friedrich] Brandt, apoyarán a estos señores en la determinación de los especímenes y la publicación de las novedades que encuentren”. En síntesis, una red de colaboradores. En realidad, ya remitidas por Hoffmann desde Costa Rica, Klotzsch identificó una gran cantidad de plantas en el Museo Botánico de Berlín, al igual que lo hicieron con animales Wilhelm Peters (mamíferos), Jean Louis Cabanis (aves), Friedrich Klug (insectos) y Carl von Martens (moluscos), en el Museo Real de Zoología de Berlín.

Fallecido Hoffmann precozmente, von Frantzius continuó la relación con Peters y Cabanis, pues su interés se centraba en los mamíferos y aves. Sin embargo, debido a algunos problemas logísticos, que implicaron la pérdida de especímenes durante tan larga travesía hasta Berlín, así como por la mayor afinidad de nuestra biota con la de Norteamérica, a partir de 1862 él estableció contacto con Spencer F. Baird (Figura 9A), en el Instituto Smithsoniano. Esta colaboración resultaría muy fructífera, ya que, como consecuencia de los envíos de aves y mamíferos para su identificación allá, en 1869 von Frantzius publicaría los dos primeros catálogos de nuestra fauna: Distribución geográfica de las aves costarricenses, su modo de vivir y costumbres y Los mamíferos de Costa Rica; contribución para el conocimiento de la extensión geográfica de los mamíferos de América.

Además, cuando en 1868 von Frantzius retornó a Alemania — tras casi 15 años de residir en nuestro país—-, llevó consigo al joven José Cástulo Zeledón (Figura 9B), para que efectuara la ya citada pasantía en Washington, la cual se prolongó por cuatro años, y dio como resultado la conversión de Zeledón en ornitólogo y mastozoólogo. Además de que éste cumpliría una función clave en la gestación del Museo Nacional, años después propició dos visitas del experto Robert Ridgway (Figura 9C), con quien había trabajado en el Instituto Smithsoniano, de modo que esta alianza continuó dando importantes réditos científicos. 
Figura 9. Baird (A), Zeledón (B) y Ridgway (C).

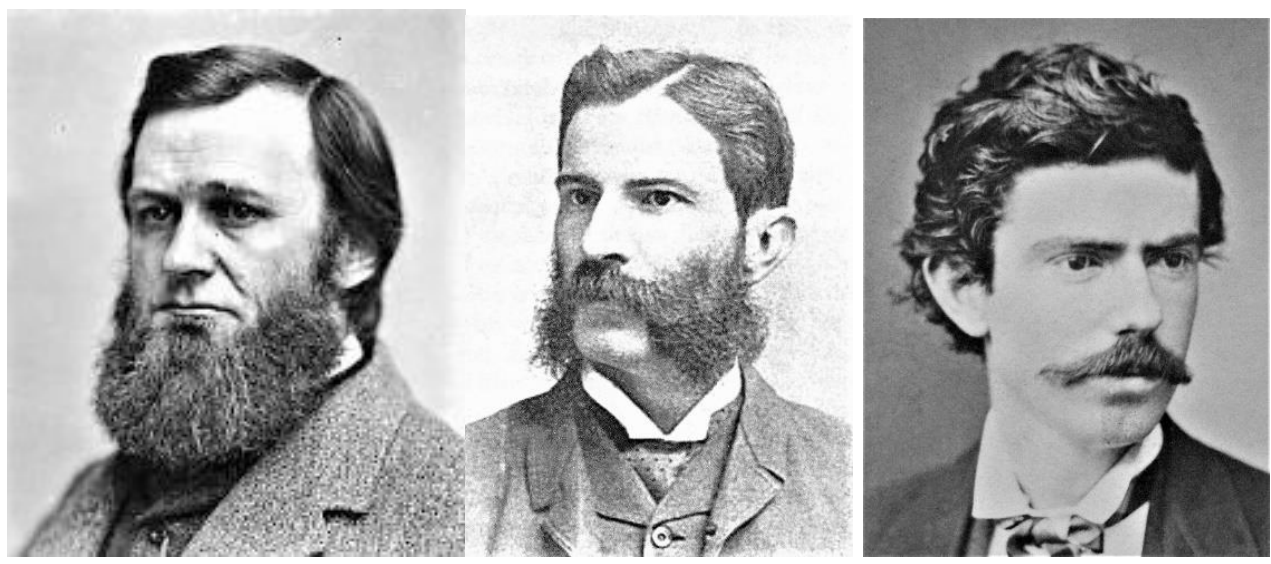

\section{Fundación de entidades científicas clave}

Para comenzar, es importante señalar que, en aquel momento, una gran limitante era que no había dónde ni cómo mantener colecciones propias. Sin embargo, con la fundación del Museo Nacional en 1887 y del Instituto Físico-Geográfico Nacional en 1889, por iniciativa de Alfaro y Pittier, respectivamente, se pudo resolver esta situación.

En consecuencia, con la ayuda de varios taxónomos europeos, vio la luz la obra Primitiae Florae Costaricensis, escrita de manera conjunta por Henri Pittier y el reputado taxónomo belga Théophile Durand, del Jardín Botánico de Bruselas; constó de tres volúmenes y 12 fascículos, aparecidos entre 1891 y 1905. Asimismo, como continuación de este esfuerzo, y gracias a la colaboración de los botánicos del Museo Nacional, que le ayudaron en la recolección de unos 15.000 ejemplares de plantas, entre 1937 y 1938 el estadounidense Paul C. Standley publicó la obra Flora de Costa Rica, la cual consta de cuatro partes y abarcó 6085 especies.

Como culmen de tan importantes logros, ya en el presente siglo, después de 30 años de investigación, en 2020 culminó el proyecto Manual de Plantas de Costa Rica, que dio origen a una obra de ocho volúmenes, referidos a 9360 especies, muchas nuevas para la ciencia. Fue coordinado por Michael H. Grayum y Barry E. Hammel, del Jardín Botánico de Missouri, y contó con el apoyo de varios botánicos extranjeros de diversas instituciones, y tuvo como contrapartes a botánicos del Museo Nacional, la Escuela de Biología de la Universidad de Costa Rica (UCR) y el propio INBio, además de que — al inicio del proyecto—, involucró a numerosos parataxónomos en casi todo el territorio nacional.

Otro excelente ejemplo de una red internacional de la que se benefició Costa Rica, fue el proyecto que culminó con la publicación de la obra Biologia Centrali-Americana. Emprendido por los entomólogos y ornitólogos ingleses, Frederick DuCane Godman y Osbert Salvin, y financiado por el primero, gracias al apoyo científico de numerosos taxónomos europeos y estadounidenses, se publicaron 257 tomos (215 de zoología, 25 de botánica y 17 de arqueología) a lo largo de casi 36 años de fructíferas labores, entre 1879 y 1915. Dichos volúmenes contienen información acerca de 50.263 especies, de las que 19.263 
Revista Herencia, Vol. 35 (1), enero-junio, 2022.

(38\%) eran nuevas para la ciencia; asimismo, está ilustrada con 1677 láminas (Figuras 10AB), para un total de 18.587 dibujos. Aunque ellos no estuvieron en Costa Rica, financiaron a los recolectores Enrique Arcé y H. Rogers, a la vez que recibieron especímenes de colaboradores locales, como Biolley, Pittier, Underwood, Lankester y José Fidel Tristán, más el dentista Charles Van Patten.

Figura 10. Láminas representativas, correspondiente a la planta Ipomoea quamoclit (A) y las mariposas Caligo memnon y C. telamonius (B).

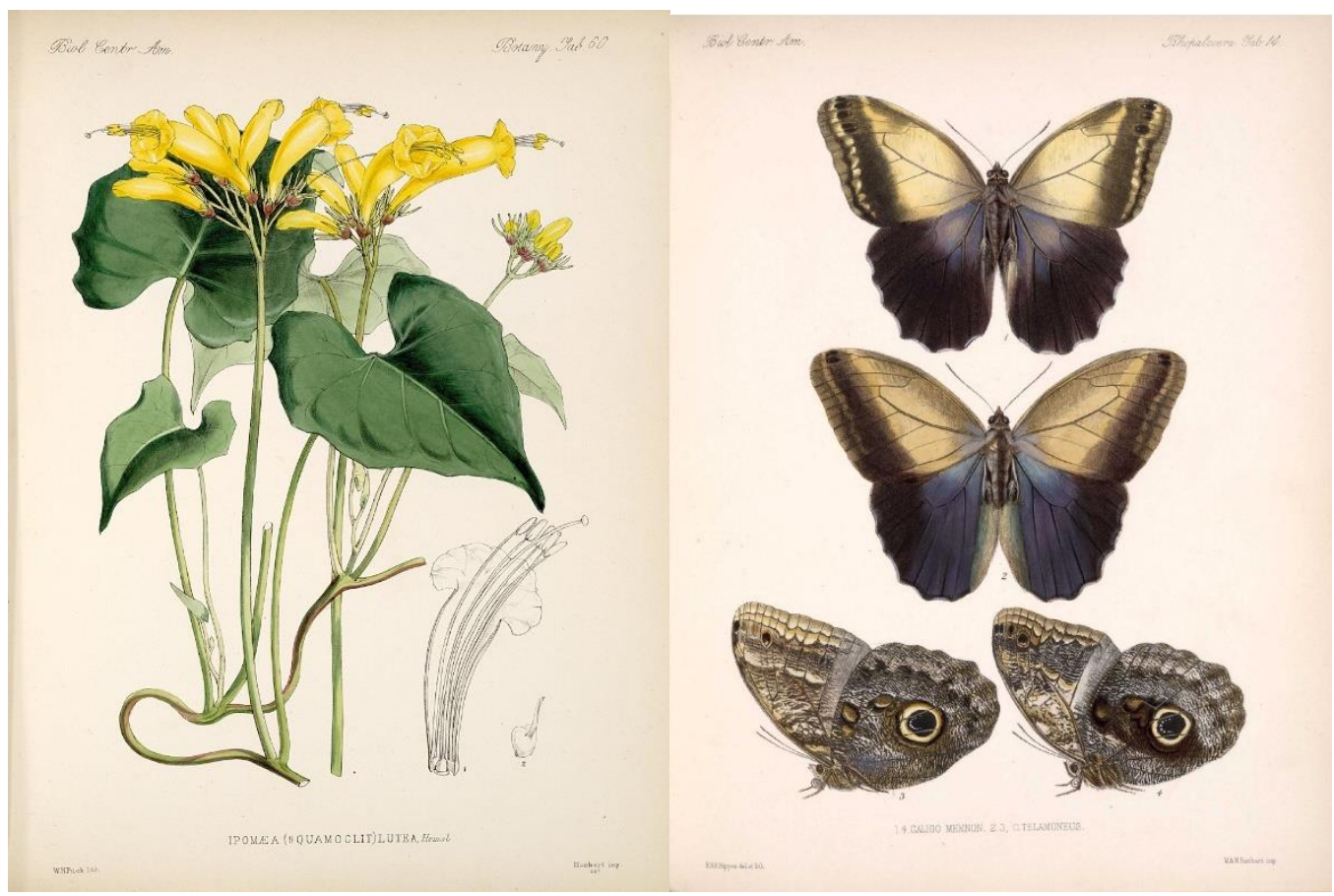

Ahora bien, las alianzas hasta aquí descritas se focalizan en el conocimiento y el inventario de la flora y la fauna per se, sin necesariamente abordar o profundizar en aspectos de las relaciones ecológicas, genéticas o evolutivas de los grupos taxonómicos estudiados.

En tal sentido, fue más que oportuno y providencial el surgimiento, en 1963, de la Organización para Estudios Tropicales (OET), gracias a la visión y los empeños del herpetólogo Jay M. Savage y el célebre botánico Rafael Lucas Rodríguez Caballero, director del Departamento de Biología de la UCR. Se trata de un consorcio académico, conformado inicialmente por siete universidades estadounidenses y la UCR, el cual, con los años, se amplió con varias decenas de universidades e instituciones estadounidenses y de otros países, más la Universidad Nacional (UNA), el Instituto Tecnológico de Costa Rica (TEC), la Universidad Estatal a Distancia (UNED) y el Museo Nacional en el ámbito local (Burlingame, 2002; Rocha y Braker, 2021). Tras casi 60 años de fructífera relación, dicha entidad tiene hoy su sede en la UCR y posee estaciones biológicas en zonas representativas de varios lugares de vida sensu Holdridge, en el territorio nacional (La Selva, en Sarapiquí, Palo Verde en Guanacaste y el Jardín Botánico Wilson, en San Vito). 
Revista Herencia, Vol. 35 (1), enero-junio, 2022.

En realidad, la creación de la OET vino a revolucionar en gran medida la manera de hacer ciencia en el país, gracias a la llegada de prestigiosos científicos, especialmente de las universidades de Southern California, Miami, Kansas, Harvard, Florida, Washington y Michigan. Varios de ellos permanecían por períodos cortos — seis semanas, comúnmentepara coordinar y dictar cursos de campo para estudiantes estadounidenses, en los que se podían matricular algunos estudiantes locales con el grado de bachiller en Biología. Eventualmente también hubo cursos en español, para estudiantes latinoamericanos. Hasta hoy, de estos cursos de postgrado se han beneficiado unos 3500 estudiantes, tanto estadounidenses, como de otros países.

Quienes tuvimos la fortuna de tomar el curso de Ecología de Poblaciones - y después fungir como asistentes y hasta profesores, en años posteriores - disfrutamos de una oportunidad formativa única. En realidad, en esas jornadas de hasta 15 horas diarias de investigación inmersos en el mundo real, complementada con conferencias, discusiones y debates, nos alejamos de lo libresco, para captar a cabalidad, como una auténtica vivencia, los complejos fenómenos y mecanismos que explican y determinan la abundancia, la estructura, la funcionalidad, la distribución y la persistencia de la biota tropical, así como sus interrelaciones con el entorno físico. Desde el punto de vista de la enseñanza de las ciencias biológicas, esos cursos intensivos de biología de campo representaron una especie de parteaguas o hito, vale decir, "un antes y un después" en la forma de percibir y entender la naturaleza tropical, y desde entonces ese enfoque y esa metodología las hemos aplicado a nuestros estudiantes durante la vida académica, como investigadores y docentes.

No obstante, es oportuno destacar que, casi desde siempre, los profesores de algunas universidades estadounidenses también han emprendido proyectos de largo plazo - como parte de los cuales sus estudiantes han podido efectuar sus tesis de postgrado-, para entender mejor el funcionamiento de los ecosistemas tropicales y su conservación. Algunos de ellos son Jay M. Savage, Gordon Orians, Carl Rettenmeyer, Norman J. Scott, Edward O. Wilson, Peter Raven, Daniel Janzen, John Vandermeer, Lawrence E. Gilbert, Gordon W. Frankie, Allen M. Young, Mildred Matthias, Monte Lloyd, Theodore Fleming, Raymond Heithaus, Don E. Wilson, Paul Opler, Alwyn H. Gentry, John J. Ewel, Kamaljit S. Bawa, Robert K. Colwell, Lucinda A. McDade, Henry Hespenheide, Gary S. Hartshorn, Milton y Diana Lieberman, David Clark, Deborah A. Clark, James L. Hamrick, Julie S. Denslow, Robin L. Chazdon, Robert J. Marquis, Bette Loiselle, Elizabeth Losos, John Longino, Ian Gauld y Lawrence R. Kirkendall.

Las actividades de investigación conducidas por estos expertos, han dado origen a un inmenso acervo de información sobre la biota de Costa Rica, divulgada en revistas científicas, libros y otros tipos de documentos. Por ejemplo, solamente de investigaciones en La Selva, hasta hoy han resultado más de 4500 publicaciones.

\section{Alianzas fructíferas de las universidades}

Ahora bien, además de esta prolongada y productiva relación académica y científica, a lo largo de los siglos XX y XXI ha habido importantes convenios entre universidades locales y algunas entidades extranjeras, en campos específicos y de gran importancia para Costa Rica. 
Por ejemplo, gracias a la Agencia de Cooperación Internacional del Japón (JICA), en 1974 la UCR pudo obtener por donación el primer microscopio electrónico -único en América Central y el Caribe - y fundar la Unidad de Microscopía Electrónica, hoy convertida en el Centro de Investigaciones en Estructuras Microscópicas. Asimismo, en 1984 se inició en la UNA el Programa Regional en Manejo de Vida Silvestre para Mesoamérica y el Caribe, que dio origen al actual Instituto Internacional en Conservación y Manejo de Vida Silvestre (ICOMVIS), gracias al apoyo del Servicio de Pesca y Vida Silvestre de EE.UU. Finalmente, por 15 años, entre 1981 y 1996, el gobierno de Holanda apoyó a la UNA con el programa de investigación Ecología y Manejo de la Vegetación de Montañas Altas en Costa Rica (ECOMA), así como por siete años el Proyecto Regional de Apicultura y Meliponicultura (PRAM), embrión del actual Centro de Investigaciones Apícolas Tropicales (CINAT).

Un caso que merece especial mención es el INBio, ente nacional de carácter público y sin fines de lucro, surgido en 1989 como resultado de la organización del naciente MIRENEM, hoy Ministerio de Ambiente y Energía (MINAE). El INBio no solo representó una gran alianza, en la que confluyeron universidades y otras entidades relacionadas con la ciencia o la conservación de la naturaleza, sino sobre todo una innovadora y fecunda alianza internacional. En efecto, con una notable capacidad de convocatoria, el INBio logró atraer a cuando menos 450 renombrados taxónomos de Norte y Sur América, Europa y Asia — la denominada "taxasfera" - para, en una especie de mutualismo, en la que todas las partes derivaban beneficios científicos, y sin costo alguno para el gobierno - ya que era financiada por agencias donantes e individuos filántropos-, efectuar la mayor colección biológica en la historia del país, como se indicó previamente.

Dicha colección hoy está en manos del Museo Nacional, pero es mucho más que una mera colección de especímenes. En efecto, ella incluye toda la información biológica asociada con los ejemplares de plantas y animales, totalmente informatizada en una base de datos y fácilmente accesible al público. La idea que logró implementarse consistió en obtener nueva información de campo, integrarla mediante métodos informáticos con los datos previamente conocidos - provenientes de otras fuentes nacionales e internacionales-y colocarla en formatos adecuados, según las necesidades de diferentes usuarios, en campos como el propiamente científico, el del conservacionismo, la educación, el ecoturismo, etc. Este ha representado un logró inédito en Costa Rica.

En síntesis, se puede afirmar que, gracias en gran medida a las oportunas y fecundas alianzas científicas internacionales concretadas en el último siglo y medio, en la actualidad Costa Rica es uno de los países tropicales cuya flora y fauna han sido más estudiadas y son mejor conocidas.

Para concluir, un campo que amerita un reconocimiento particular es la biología marina. Aunque el mar territorial de Costa Rica equivale a una superficie once veces mayor que la terrestre, y contiene cerca del 3,5\% de la biodiversidad marina del planeta (Wehrtmann y Cortés, 2009), no ha recibido la debida atención, históricamente. Sin embargo, en 1979 la UCR fundó el Centro de Investigación en Ciencias del Mar y Limnología (CIMAR), en tanto que la UNA estableció la carrera de Biología Marina en 1979. Además, la UNA tiene dos sedes de investigación en Puntarenas, la Estación Nacional de Ciencias Marinas y Costeras 
Revista Herencia, Vol. 35 (1), enero-junio, 2022.

(ECMAR), en Punta Morales —establecida con el financiamiento del Consejo Nacional de Investigaciones Científicas y Tecnológicas (CONICIT) — y la Estación de Biología Marina Juan Bertoglia Richards. Aunque estos entes de la UCR y la UNA surgieron como iniciativas endógenas, a lo largo del tiempo y de varias maneras han contado con el apoyo de especialistas extranjeros.

\section{Conciencia de la necesidad de institucionalizar las ciencias biológicas}

\section{Dos instituciones científicas y una masa crítica}

Como se indicó en páginas previas, la primera idea formal de fundar un museo nacional y un jardín botánico en el país data de 1849, por iniciativa de don Juanito Mora, para lo cual recibió una propuesta de Louis Chéron, un culto francés residente en el país. No obstante, en el primer caso, se trataba de un espacio físico dedicado exclusivamente a la exhibición de muestras biológicas y mineralógicas, así como de objetos arqueológicos y etnográficos. Quizás ello obedecía a que, hasta entonces, los especímenes recolectados en el territorio nacional por los pocos naturalistas europeos que lo habían recorrido, permanecían en los museos donde trabajaban los taxónomos a quienes ellos se los habían enviado para que los identificaran.

Por diferentes circunstancias, esa idea quedó flotando en el aire, y no sería casi 40 años después cuando, gracias a los empeños de Anastasio Alfaro (Figura 11A), en 1887 se creó el Museo Nacional. Además, por iniciativa de Pittier, al año siguiente se estableció el Instituto Meteorológico, que a partir de 1889 se denominaría Instituto Físico-Geográfico Nacional.

Figura 11. Alfaro (A), Cherrie (B), Underwood (C) y Wercklé (D).
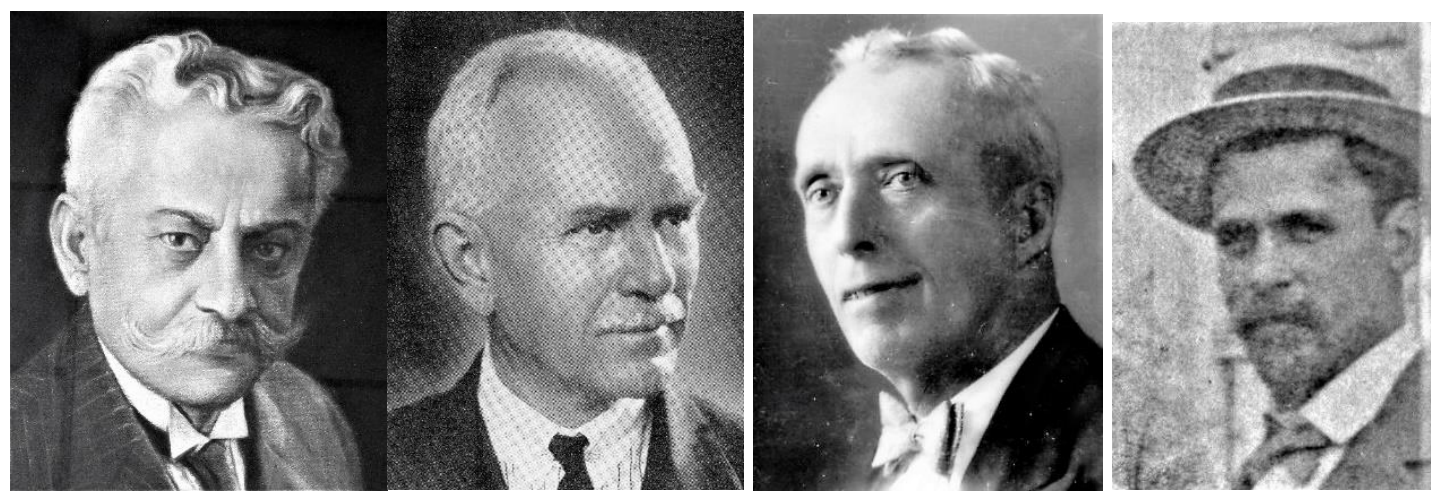

Esto ocurrió durante la administración de Bernardo Soto Alfaro quien, en congruencia con su orientación liberal, estaba dispuesto a fortalecer la ciencia y la tecnología, para lo cual era imprescindible asignar fondos estatales para reclutar personal de alta calidad, así como para gastos operativos y administrativos de cada entidad. Fue así como en 1889, para el Museo Nacional, se contrató al estadounidense George Kruck Cherrie y al inglés Cecil Francis Underwood Dodd (Figuras 11B-C) — al inicio, éste fue financiado por el Museo Americano de Historia Natural-, que se dedicaron a la recolección de aves, mamíferos y reptiles, mientras que para el Instituto Meteorológico — donde se albergaba el Herbario Nacional- 
Revista Herencia, Vol. 35 (1), enero-junio, 2022.

se reclutó en Suiza al botánico Tonduz. Además, en 1902 recalaría en el país el botánico alsaciano Carlos Wercklé Deher (Figura 11D), a quien en cierta época se le apoyó económicamente. Recuérdese que, además, en ese momento también residía en el país Paul Biolley, estudioso de insectos y moluscos.

La existencia de estos dos recintos no solamente hizo posible el anhelado sueño de acopiar información biológica, geológica, geográfica, climática y etnográfica, así como de exhibir muestras biológicas, mineralógicas y arqueológicas, sino algo aún más importante. En efecto, es de suponer que ahí casi todos los días confluían los citados investigadores, favorecidos por la cercanía física de ambos entes, ya que estaban separados por apenas un cuadrante capitalino; el Museo Nacional ocupaba una porción del edificio de la Universidad de Santo Tomás, diagonal al actual Teatro Nacional, en tanto que el Instituto Físico-Geográfico Nacional se localizaba en el antiguo predio del Liceo de Costa Rica, en la Avenida 2a, ocupado hoy por el edificio de la Caja Costarricense del Seguro Social.

Es lógico suponer que, mientras efectuaban sus labores cotidianas de preparación de especímenes de plantas y animales, conversaban sobre aspectos atinentes a las ciencias naturales, como sus hallazgos e inquietudes científicas e hipótesis, así como aspectos de la correspondencia recibida de taxónomos extranjeros, al igual que ideas derivadas de sus nuevas lecturas en revistas y libros científicos (Figura 12). De esta manera se fue configurando una masa crítica, es decir, un foco o núcleo de reflexión acerca de sus observaciones de campo, a la vez que de discusión de ideas, percepciones y nuevos planteamientos. Esto representó un salto cualitativo sin precedentes en el país, además de que, al lado de ellos, auténticos mentores, se fueron formando como científicos algunos jóvenes prospectos. Es decir, fue bajo la égida de Pittier, Biolley, Tonduz, Cherrie, Underwood y Wercklé como emergieron nuestros primeros naturalistas. 
Figura 12. Alfaro (con traje), los taxidermistas Cherrie (de pie) y Underwood (sentado), más un joven ayudante, circa 1893, en la primera sede del Museo Nacional.

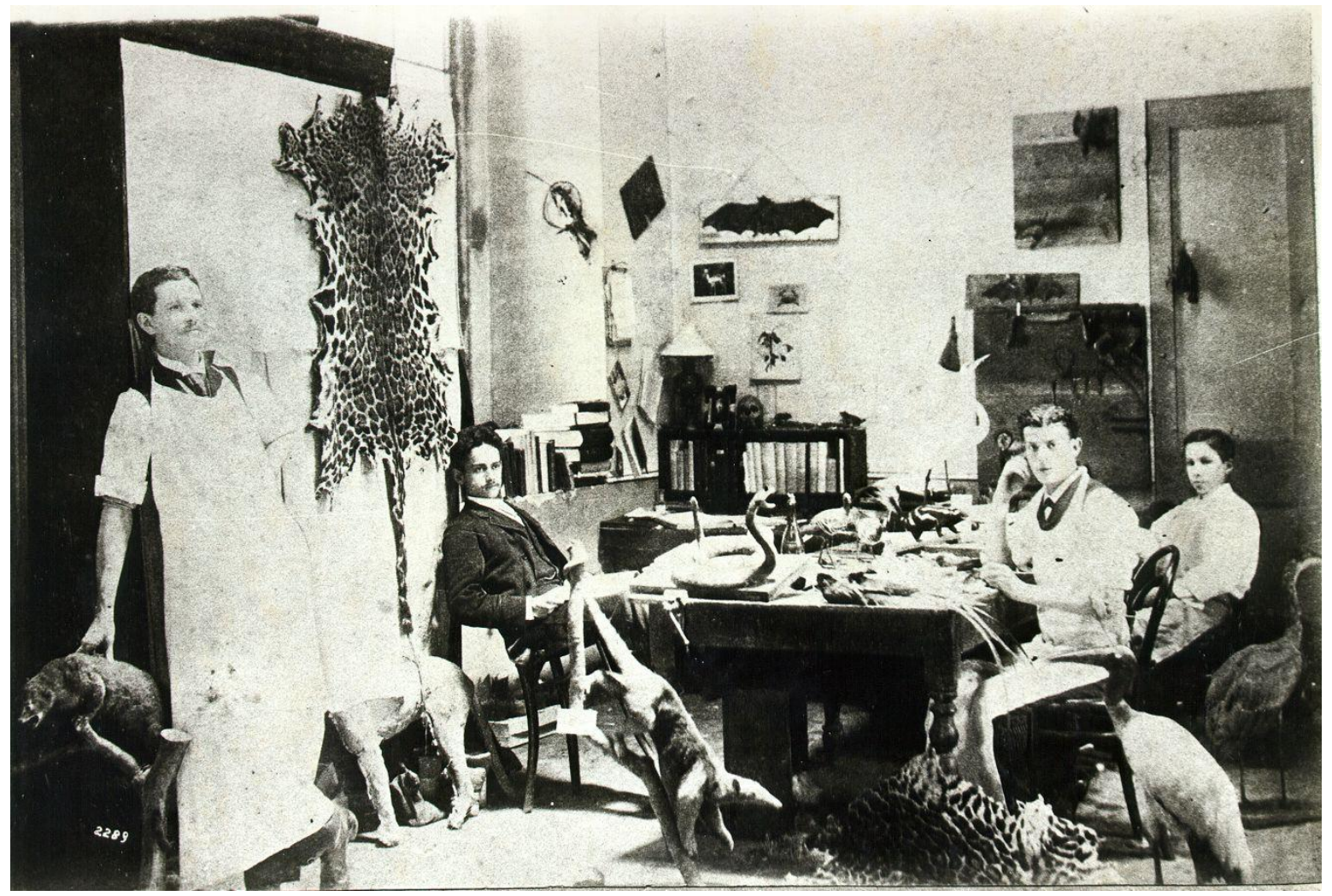

Al respecto, debe recordarse que José Cástulo Zeledón había aprendido taxidermia mientras laboraba en la botica de von Frantzius, al igual que Juan José Cooper Sandoval, pero tuvo la invaluable oportunidad de realizar la ya mencionada pasantía en el Instituto Smithsoniano; no obstante, Cooper laboró para el Museo Nacional, y fue un gran recolector de plantas y animales. En el caso de Alfaro, aunque era el director del Museo Nacional — puesto que asumió con apenas 22 años de edad-, esta interacción cotidiana le permitió cimentar su formación de naturalista; él había sido inspirado por el catalán Torres Bonet, quien era docente y no investigador, por lo que su formación estaba incompleta. Asimismo, con el tiempo surgirían José Fidel Tristán Fernández (Figura 13A), discípulo de Biolley, al igual que los botánicos Otón Jiménez Luthmer y Alberto Manuel Brenes Mora (Figuras 13B-C), formados bajo la tutela de Tonduz y Pittier, respectivamente. De los seis, Brenes fue el único que tuvo acceso a educación biológica formal y de alto nivel, gracias a una beca para formarse como botánico en Suiza.

De esta manera empezaba a cristalizar el sueño - explícito o no-, de lograr la institucionalización de nuestras ciencias naturales. 
Revista Herencia, Vol. 35 (1), enero-junio, 2022.

Figura 13. Primera generación de naturalistas costarricenses: Tristán (A), Jiménez (B) y Brenes (C).
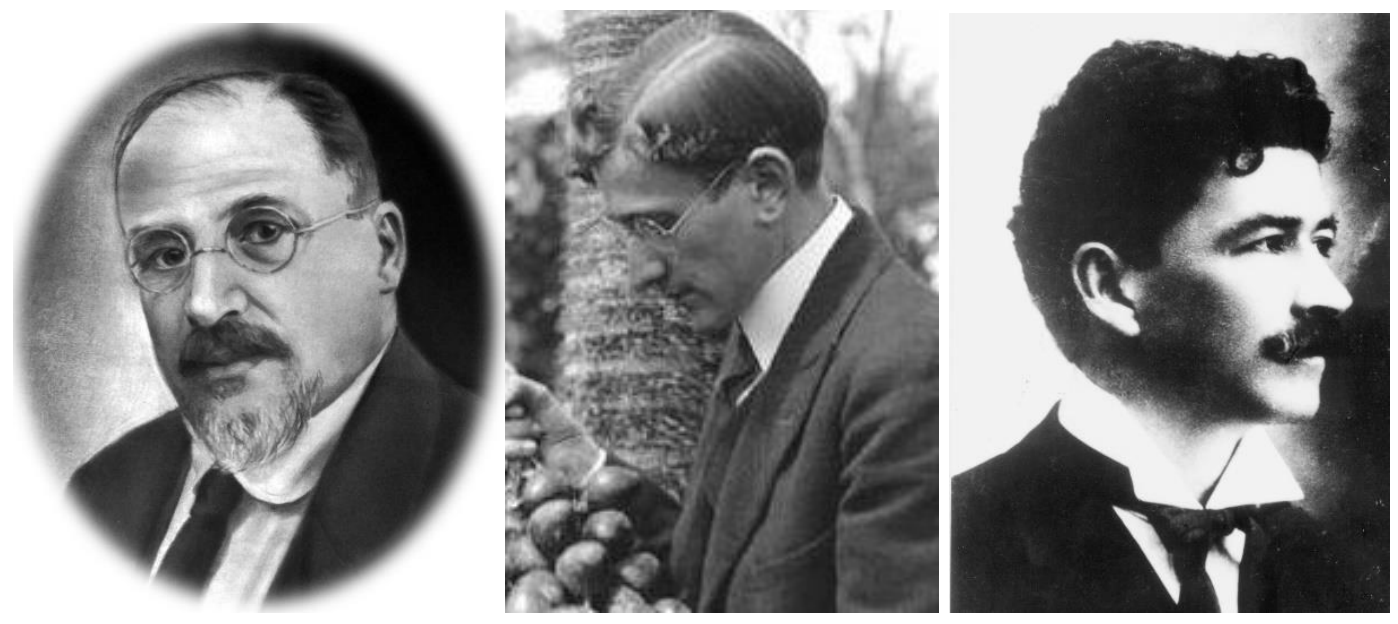

\section{La producción de revistas y libros científicos propios}

El citado desiderátum se amplió y reforzó con la visión de Alfaro y Pittier, de editar publicaciones científicas, inexistentes hasta entonces en el país. Fue así como en 1887 Alfaro fundó la revista Anales del Museo Nacional de Costa Rica, en tanto que Pittier estableció en 1889 los Anales del Instituto Físico-Geográfico Nacional. En contraste con estas revistas, de carácter formal, en 1901 se creó el Boletín del Instituto Físico-Geográfico Nacional, de naturaleza más bien divulgativa, pero no para el público general, sino para lectores con cierto nivel educativo; expiró en 1904. Conviene resaltar que, además de publicar los nuevos hallazgos de los investigadores de ambas entidades, Pittier emprendió la meritoria labor de traducir al español algunos trabajos fundamentales de nuestra historia natural, para así recuperar parte del acervo científico del país.

Cabe acotar que, a partir de 1890, las revistas de ambas entidades se fusionaron, con el título Anales del Instituto Físico-Geográfico Nacional y del Museo Nacional de Costa Rica. De muy corta vida, en 1896 esta publicación expiró, lo cual provocó un vacío de casi 60 años en la difusión de la información biológica y científica generada localmente. Sin embargo, en 1953 surgiría la Revista de Biología Tropical en la UCR, enfocada tanto hacia la biología fundamental como a las ciencias biomédicas. En ello fue clave el liderazgo del profesor y médico italiano Ettore De Girolami, junto con el parasitólogo Alfonso Trejos Willis. Hoy, casi 70 años después, y tras superar numerosas adversidades y vicisitudes económicas, a las cuales su director Rafael Lucas Rodríguez supo hacerles frente, representa un auténtico foro mundial en el campo de la biología de los trópicos. Conviene destacar que en 1972 se le sumó la extinta revista Brenesia, fundada por el naturalista Luis Diego Gómez Pignataro, como director del Museo Nacional.

Asimismo, aunque no todas existen hoy, en el curso de los años emergieron otras revistas universitarias, lo que denota una producción constante de nueva y abundante información en las ciencias biológicas. Casi toda esta información se puede accesar por vía electrónica en la 
Revista Herencia, Vol. 35 (1), enero-junio, 2022.

excelente base de datos BINABITROP (Bibliografía Nacional en Biología Tropical), de la Organización para Estudios Tropicales.

Las mencionadas revistas incluyen Uniciencia (1984), Lankesteriana (2001) y Biocenosis (1979), en la UNA, la UCR y la UNED, respectivamente. Además, surgieron revistas — no todas vigentes hoy - que, aunque se focalizan en los campos forestal, agrícola y de salud pública, también acogen artículos en biología básica, como Turrialba (1950), Manejo Integrado de Plagas y Agroecología (1986), Agroforestería en las Américas (1997), Revista Forestal Centroamericana (1992) y Recursos Naturales y Ambiente (2004), en el IICACATIE, al igual que la Revista de Ciencias Ambientales (1980), Vida Silvestre Neotropical (1993) y Revista Ciencias Marinas y Costeras (2009) en la UNA, la Revista Forestal Mesoamericana Kurú (2004) en el TEC, así como Agronomía Costarricense (1977) y Agronomía Mesoamericana (1989) en la UCR.

Para retornar al Instituto Físico-Geográfico, en 1904 fue absorbido por el Museo Nacional, el cual -bajo la dirección de Alfaro por unos 30 años- continuó su proceso de consolidación. Además, en ausencia de una universidad en el país, se convirtió en el recinto natural y exclusivo para atraer a numerosos especialistas extranjeros interesados en explorar nuestra naturaleza, sobre todo estadounidenses. Conviene acotar que, entre 1944 y 1952, el Museo Nacional se convirtió en una dependencia de la UCR (Kandler, 1987).

Fue de esta manera como, hasta mediados del siglo $\mathrm{XX}$, el conocimiento de nuestra biota se pudo incrementar hasta niveles realmente extraordinarios, gracias a los aportes de varios notables científicos, quienes permanecieron por períodos más o menos prolongados en el país. Entre ellos sobresalieron los botánicos Paul C. Standley, John Donnell Smith y Paul Allen; los entomólogos Philip y Amelia Calvert; el ictiólogo Seth Meek; los herpetólogos Emmett Dunn, Edward Taylor y Archie Carr; los ornitólogos Melbourne Carriker, Austin Smith y Paul Slud; y el mastozoólogo Eugene Hall.

Es oportuno destacar que algunos de ellos publicaron obras enjundiosas y comprensivas no necesariamente como libros, sino como monografías en revistas científicas-, como la ya citada Flora de Costa Rica (Standley, 1937-1938), al igual que Un año de historia natural de Costa Rica (Calvert y Calvert, 1917), Una lista anotada de las aves de Costa Rica, incluyendo la isla del Coco (Carriker, 1910), y Las aves de Costa Rica: distribución y ecología (Slud, 1964). Un caso particular es el de los mastozoólogos estadounidenses Joel Asaph Allen y George Gilbert Goodwin, quienes estudiaron mucho material proveniente de Costa Rica, y tanto se identificaron con el país, que el segundo escribió la monografía Mamíferos de Costa Rica (Goodwin, 1946). De estas obras, solo la primera está traducida al español. De manera indirecta, todas ellas, consideradas como clásicos en su respectiva disciplina, son también el resultado de la institucionalización de nuestras ciencias biológicas.

En los últimos años, por fortuna, la actividad editorial relacionada con las ciencias biológicas ha florecido de manera espléndida, especialmente con la intensa labor editorial que desplegara el INBio, que produjo libros — varios de ellos bilingües_-, profusamente ilustrados con imágenes en colores, para facilitar la identificación de las especies mencionadas. A ello se sumó el Sistema de Información sobre Biodiversidad Atta, que 
Revista Herencia, Vol. 35 (1), enero-junio, 2022.

permite tener acceso a las bases de datos del INBio, con información e imágenes de especies de plantas y animales existentes en Costa Rica, así como de su distribución en el país.

En consecuencia, hoy se cuenta con numerosos libros, bastante completos, sobre nuestras flora y fauna, algunos de ellos escritos por autores nacionales, solos o en coautoría con extranjeros.

Entre dichos libros, en el campo botánico destacan dos volúmenes referidos a macrohongos (Mata, 2003; Mata et al., 2003), uno a líquenes (Umaña y Sipman, 2002), uno a bromelias (Morales, 2000), cinco a orquídeas (Morales, 2009), dos a plantas ornamentales nativas (Hammel, 2005; Rojas et al., 2016), uno a guabas y cuajiniquiles (Zamora y Pennington, 2001), cuatro a taxonomía de árboles (Holdridge et al., 1997.; Zamora et al., 2000, 2003, 2017), y dos a árboles maderables (Jiménez et al., 2011, 2016). Además, existen libros sobre árboles y otras plantas de zonas particulares, así como uno acerca de algas y plantas presentes en arrecifes coralinos (Cortés y León, 2002).

Por su parte, en el campo zoológico, de animales invertebrados hay información sobre especies de corales en el libro recién citado, al igual que en uno sobre biodiversidad marina (Wehrtmann y Cortés, 2009), así como libros específicos sobre escorpiones (Víquez, 1999), homópteros (Godoy et al., 2005), moscas (Zumbado, 1999; 2006), escarabajos (Solís, 2002), mariposas (DeVries, 1987, 1997; Chacón y Montero, 2007), himenópteros (Ugalde, 2002; Gauld y Hanson, 1995) y abejas (Hanson et al., 2021). De animales vertebrados, se cuenta con obras sobre peces (Bussing, 1987), anfibios y reptiles (Savage, 2002), serpientes (Solórzano, 2004), aves (Stiles y Skutch, 1995), mamíferos (Carrillo et al., 1999), murciélagos (LaVal y Rodríguez, 2002) y mamíferos marinos (Sáenz et al., 2004). A ellas se suman libros sobre grupos faunísticos en áreas de conservación específicas.

A todas estas publicaciones impresas, y a tono con las necesidades y demandas del mundo actual - dominado por la cibernética y los multimedios - , se cuenta con excelentes bases de datos, como el Atlas de la Biodiversidad de Costa Rica (CRBio) y las del Museo Nacional y la Comisión Nacional para la Gestión de la Biodiversidad (CONAGEBIO). Dichos recursos han facilitado inmensamente el acceso a la información acerca de nuestra biota, que antes se podía conseguir mediante la visita a museos o la consulta a publicaciones científicas no siempre disponibles en el país.

\section{La formación de biólogos en las universidades}

Ahora bien, para retornar a la auspiciosa época de la creación del Instituto Físico-Geográfico y el Museo Nacional, gracias a ambos entes se fueron formando otros jóvenes prospectos aparte de Alfaro, Tristán, Jiménez Luthmer y Brenes-, como Clodomiro (Clorito) Picado Twight, José María Orozco Casorla, los hermanos Juvenal y Rómulo Valerio Rodríguez, Manuel Valerio Alvarado, Rubén Torres Rojas, Manuel Quirós Calvo, Jorge León Arguedas y Rafael Lucas Rodríguez (Figuras 14A-D). Entre todos ellos sobresalió Picado quien, en contraste con todos los naturalistas previos, los cuales se dedicaron sobre todo a la taxonomía y la historia natural, fue el primero - ya con el título de doctorado, obtenido en la 
Revista Herencia, Vol. 35 (1), enero-junio, 2022.

Universidad de París - en emplear métodos experimentales en sus investigaciones biológicas.

Figura 14. Algunos naturalistas costarricenses de la segunda generación: Picado (A), Orozco (B), León (C) y Rodríguez (D)
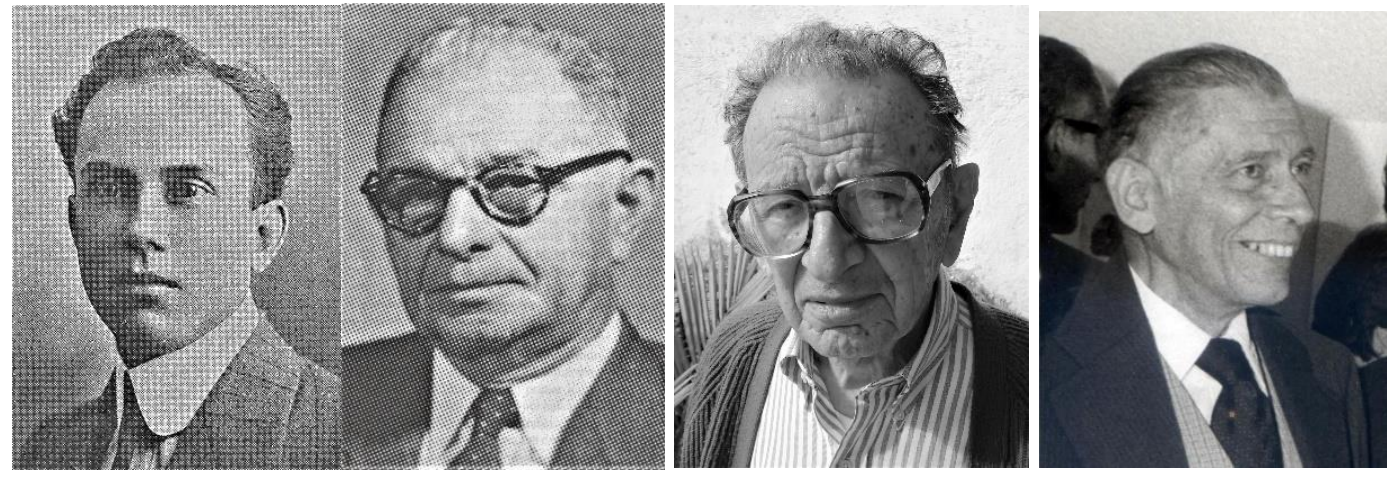

Fue gracias a estos científicos, así como al sólido y creciente acervo de conocimientos biológicos acumulado hasta entonces, que se pudo dar el segundo gran paso en la institucionalización de nuestras ciencias biológicas, como lo fue la formación de profesionales. Esto fue posible a partir de 1940, con la fundación de la Universidad de Costa Rica, tras más de medio siglo de carecerse de universidad. En dicha entidad, en 1957 se estableció el Departamento de Biología, para dar servicio a varias carreras (ciencias biomédicas y agronomía), así como para contribuir con la Facultad de Educación en la formación de profesores para secundaria; en ello fue figura clave el recién citado Rodríguez (Rodríguez, 2018).

Años después, se convirtió en una escuela con carrera propia hasta el grado de licenciatura - con énfasis en botánica, zoología, genética y ecología-, y hoy ofrece el grado de Magister Scientiae. Asimismo, años después, dicha entidad estableció un herbario y el Museo de Zoología que, junto con el Museo de Insectos de la Facultad de Agronomía, también empezaron a atraer especialistas extranjeros, en complementariedad con el Museo Nacional.

Un hecho de gran trascendencia para el país ha sido la inversión estatal en la formación de recursos humanos en el campo de las ciencias biológicas, no solo en la UCR, sino también en las otras universidades públicas (TEC, UNA y UNED), fundadas en 1971, 1973 y 1977, respectivamente.

En efecto, según las cifras oficiales del Consejo Nacional de Rectores (CONARE), los graduados en el presente siglo (2000-2019) corresponden 1811 bachilleres (Portal Hipatia, Proyecto Estado de la Nación), pero de acuerdo con los registros de las respectivas escuelas en dichas universidades, el acumulado histórico es de 2463 bachilleres. Todos ellos están calificados profesional y legalmente para ejercer su profesión. Cabe acotar que en los últimos años ha tomado mucha fuerza la biotecnología, especialmente en el TEC y la UNA. 
Revista Herencia, Vol. 35 (1), enero-junio, 2022.

Asimismo, en cuanto a grados superiores, del total histórico de bachilleres al menos 681 han alcanzado el grado de licenciatura, 523 el de Magister Scientiae y 135 el de doctorado académico. A ellos habría que sumar los profesionales con los grados de maestría y doctorado académico obtenidos en universidades extranjeras, o en el siglo $\mathrm{XX}$.

Es pertinente aclarar que en dichos cómputos no se incluye la inmensa cantidad de profesionales formados por otras unidades académicas en áreas aplicadas (ciencias agrícolas, forestales, veterinarias y biomédicas), al igual que aquellos graduados de la Universidad EARTH — que no forma parte del CONARE, por ser un ente internacional—, muchos de los cuales laboran en entidades y proyectos afines a las ciencias biológicas, sobre todo en acciones relacionadas con la conservación de la naturaleza.

En síntesis, hoy se cuenta con un capital humano de inestimable valor para el desarrollo científico y tecnológico del país. Y, por lo relevante y meritorio que ha sido en la evolución de nuestras ciencias biológicas, es preciso reconocer el apoyo que, desde su fundación en 1972, ha aportado el CONICIT, mediante el financiamiento de becas de postgrado — tanto dentro como fuera del país - y de proyectos de investigación.

Para concluir esta sección, es muy importante destacar que, como se indicó en páginas previas, para la célebre Reforma Universitaria de 1957 se decidió contratar profesores extranjeros de alto nivel académico.

En esos años fundacionales participaron varios zoólogos — pues se contaba con algunos botánicos nacionales-, como el italiano Antonio Balli Pranzini y los estadounidenses Archibald (Archie) Fairly Carr Jr., James L. Vial y Norman J. Scott. Además, por entonces en la Escuela Nacional de Agricultura laboraban tres destacados entomólogos, el estadounidense Charles H. Ballou y los alemanes Ferdinand Nevermann y Alexander Bierig; estos dos últimos no tenían grado universitario en biología, pero eran especialistas en coleópteros, y reconocidos como autoridades mundiales en su campo; a ellos tres se sumó el ingeniero forestal sueco Alfredo Anderson Sandberg. Fieles a esta tradición, en años posteriores, fungirían como profesores los zoólogos estadounidenses William Bussing Burhaus (peces), Douglas Robinson Clark (anfibios y reptiles), Frank Garfield (Gary) Stiles Hurd (aves) y Susan Smith (aves).

Es pertinente indicar que, en 1974, al abrir sus puertas la UNA, se crearon el Departamento de Biología - hoy Escuela de Ciencias Biológicas - y la Escuela de Ciencias Ambientales (EDECA). El artífice de ambas unidades académicas fue el biólogo Rolando Mendoza Hernández — graduado en Italia, y cuyo mentor había sido Balli en la UCR—, pero en su proceso de gestación fueron clave el genetista chileno Juan Bertoglia Richards y el ingeniero agrónomo Mario Boza Loría, respectivamente; Boza obtuvo su maestría en el CATIE, en manejo de áreas protegidas, bajo la guía del reconocido experto mundial Kenton Miller. En las etapas iniciales de la EDECA fueron relevantes los aportes de varios biólogos estadounidenses, como Christopher Vaughan (vida silvestre), Charles E. Schnell (ecología) y Donald B. Zeaser (genética forestal), así como del boliviano Mario J. Baudoin (ecología). 
Revista Herencia, Vol. 35 (1), enero-junio, 2022.

A todos estos profesionales deben sumarse algunos grandes científicos que llegaron por cuenta propia al país, como el ya citado Alexander Skutch — quien arribó en 1935—, al igual que el entomólogo y ecólogo Daniel Janzen, quien tiene medio siglo de residir a tiempo parcial en el Área de Conservación Guanacaste y es el biólogo que más ha escrito sobre la biota de Costa Rica, con al menos 500 publicaciones formales. Asimismo, hubo cuatro destacados científicos que laboraron en el CATIE, desde donde tuvieron una notable influencia en el desarrollo de nuestras ciencias biológicas; ellos son el alemán-venezolano Gerardo Budowski y los estadounidenses Kenton Miller, Leslie Holdridge y Joseph Tosi, los dos últimos fundadores del Centro Científico Tropical (CCT). Cabe acotar que Skutch fungió como profesor en la UCR, mientras que Holdridge y Tosi lo hicieron en el TEC, aunque por períodos relativamente cortos.

Tal fue el compromiso con Costa Rica de parte de todos los científicos extranjeros, citados en los últimos párrafos, que los restos de varios de ellos reposan en nuestro suelo.

\section{Consideraciones finales}

El análisis de la evolución de las ciencias biológicas en Costa Rica, mediante la categorización en las seis rutas discutidas previamente, tiene mucho de arbitrario —al igual que sucede con toda clasificación o periodización-, así como de riesgoso, por cuanto se corre el peligro de segmentar un proceso que es intrínsecamente complejo. Sin embargo, nos parece que es la mejor manera de abordarlo. En efecto, como se indicó en la Introducción, todas esas rutas están interconectadas, de modo que a veces es difícil determinar dónde empieza una o termina la otra, o cuál es el peso específico de una sobre otra.

En tal sentido, más allá de esta segregación, y a manera de síntesis o conclusión, resulta oportuno identificar las tendencias principales que se entrecruzan en las citadas rutas o vías.

En primer lugar, en cuanto a las influencias científicas más relevantes, resulta claro que, tras la estadía relativamente breve del naturalista danés Oersted, pesó de manera determinante la presencia alemana en la etapa fundacional - hasta aproximadamente 1876 - con lo cual se logró el reconocimiento de las ciencias biológicas como parte de la cultura del país. Asimismo, a partir de fines del siglo XIX, el influjo suizo fue clave para la institucionalización de nuestras ciencias biológicas, además de que casi desde entonces la influencia de científicos estadounidenses ha sido abrumadora.

En segundo lugar, muy pocos de los naturalistas que exploraron el país poseían estudios formales en ciencias biológicas - cómo era usual entonces-, sino que predominaban los médicos y farmacéuticos. No obstante, todos o casi todos tenían amplia experiencia en diferentes grupos florísticos o faunísticos. Además, respaldaban su labor en el apoyo proveniente de excelentes pares científicos y redes de colaboradores en Europa y EE.UU.

En tercer lugar, aunque de manera dogmática y hasta ideologizada, algunas personas tienden a pensar que los naturalistas que han arribado al país a lo largo de su historia lo han hecho por motivaciones de carácter colonialista o imperialista, esto no tiene asidero alguno en la realidad. Por el contrario, fuera de todo cliché — para lo cual basta con revisar cada caso—, en 
Revista Herencia, Vol. 35 (1), enero-junio, 2022.

su gran mayoría lo hicieron con fondos propios o de sus instituciones académicas, obedeciendo al impulso interior que representa la sed por la búsqueda del conocimiento, así como por la pasión que provoca el estudio de la naturaleza tropical.

En cuarto lugar, un rasgo notable es que, en varias épocas de nuestra historia, con gran visión se ha reconocido la importancia de nutrir nuestros entes de educación secundaria y universitaria con el conocimiento de profesores e investigadores provenientes de países con un alto desarrollo educacional y científico, varios de los cuales permanecieron para siempre en el país. Ello, sin duda, permitió vigorizar la docencia y la investigación en ciencias biológicas. No obstante, hoy también funcionan otros mecanismos de colaboración internacional, mediante redes entre investigadores, al igual que la formación de postgrado en universidades extranjeras de alto nivel.

En quinto lugar, desde muy temprano en la vida independiente del país, se captó la necesidad e importancia de institucionalizar y financiar actividades científicas propias, lo cual permitió la formación de los primeros botánicos y zoólogos nacionales, el desarrollo de proyectos de investigación, y el surgimiento de revistas científicas locales. Con la creación de las universidades estatales, más el apoyo del CONICIT, ha habido un impresionante potenciamiento en esos tres rubros, con varios miles de biólogos graduados, la investigación como una actividad continua y cotidiana, y varias revistas de calidad, reconocidas internacionalmente, además de que se ha consolidado el hábito de publicar los hallazgos científicos, tanto en revistas propias como en revistas internacionales de alto impacto.

Es por ello que, al celebrarse el bicentenario de nuestra independencia, no hay duda de que el balance es sumamente positivo. Hoy las ciencias biológicas están consolidadas, y ya son parte de nuestra cultura. Además, como irrefutable saldo de la labor de tantos investigadores a lo largo del tiempo - tanto nacionales como extranjeros-, contamos con detallados inventarios de nuestra biota, así como con un conocimiento profundo de nuestros principales grupos y especies de plantas y animales; tenemos un sistema de clasificación de nuestras zonas de vida y ecosistemas (eco-mapas), de gran importancia para la planificación en el uso del territorio; y se ha logrado el establecimiento y afianzamiento de un sistema nacional de áreas de conservación (SINAC) que es un ejemplo en el mundo, además de que el ecoturismo representa una importante fuente de divisas para el país.

Para concluir, a pesar de tan importantes logros, la situación como país no nos debe llevar a la autocomplacencia, ya que es mucho lo que queda por hacer. Y ello es especialmente importante en una época en que la crisis ambiental planetaria — de la que Costa Rica no puede sustraerse - representa una grave amenaza no solo para conservación de la rica biodiversidad tropical, sino también para la supervivencia de la propia especie humana.

\section{Agradecimientos}

Agradezco el aporte de información de parte de Rodrigo Gámez Lobo, Jesús Ugalde Víquez, Álvaro Herrera, Quírico Jiménez Madrigal, Elizabeth Braker, Sofía Rodríguez Brenes, Gilbert Fuentes González, Norman Scott, F. Gary Stiles, Paul Hanson, Barry Hammel, Michael Grayum, Luis Alberto Sell Biasetti, Edgar Suárez Bolaños, Orlando Morales 
Revista Herencia, Vol. 35 (1), enero-junio, 2022.

Matamoros, Dagoberto Arias Aguilar, Ángel Herrera Ulloa, Freddy Pacheco León, Christopher Vaughan, Anny Chaves Quirós, Bernal Rodríguez Herrera, Jorge Cortés Núñez, José Antonio Vargas Zamora, Federico Bolaños Vives, Jaime Brenes Madriz, Jaime García González, Olman Murillo Gamboa, María Eugenia Bozzoli Vargas, María Santos Pasamontes y Gabriel Salas Gutiérrez (Portal Hipatia, Proyecto Estado de la Nación). Asimismo, a Rodrigo Gámez, Pedro León Azofeifa y Quírico Jiménez, por sus valiosas observaciones al manuscrito original. A Theresa White, por la revisión del resumen en inglés.

Además, a las personas o entidades que facilitaron las imágenes que — con excepción de las de dominio público o las provenientes de la internet - ilustran este texto: Silvia Meléndez Dobles (1B), Ligia Carmiol Fernández (1D), Carlos Ossenbach Sauter (2B), Rolando Leiva Phillips (6A), Silvia Troyo Jiménez (8C, 13B), Bernal Rodríguez Herrera (11B-C), Rafael Lucas Rodríguez Sevilla (14D), la Editorial de la Universidad de Costa Rica (1A, 3A, 13C) y el Museo Nacional de Costa Rica (8A-B, 11A, 12, 13A). Otras fueron tomadas por el autor (4A-C, 6B, 14C). Por su parte, la 3B fue dibujada por Carlos Aguilar Durán, en tanto que las figuras 10A-B provienen de la versión electrónica de la obra Biologia Centrali-Americana, disponible en la Biodiversity Heritage Library. Finalmente, Lugene Bruno y Terry D. Jacobsen autorizaron el uso de las figuras 5A (6331.0609) y 5B (6331.1167), que forman parte de la Torner Collection of Sessé and Mociño Biological Illustrations, propiedad del Hunt Institute for Botanical Documentation, de la Carnegie Mellon University (Pittsburgh, Pensilvania).

\section{BIBLIOGRAFÍA}

Acevedo, H., Bustamante, J., Paniagua, L. \& Chaves, R. (2002). Ecosistemas de la cuenca hidrográfica del río Savegre. Editorial Instituto Nacional de Biodiversidad (INBio).

Arias, R. (2002). Del Protomedicato al Colegio de Médicos y Cirujanos de Costa Rica; 145 años de historia. Colegio de Médicos y Cirujanos de Costa Rica. Editorial Porvenir.

Boza, M. A. (2015). Historia de la conservación de la naturaleza en Costa Rica (17542012). Editorial Tecnológica de Costa Rica.

Burlingame, L. J. (2002). Evolution of the Organization for Tropical Studies. Revista de Biología Tropical 50 (2), 439-472.

Bussing, W. A. (1987). Peces de las aguas continentales de Costa Rica. Editorial de la Universidad de Costa Rica.

Calvert, A. S. \& Calvert, P. P. (1917). A year of Costa Rican natural history. The Macmillan Co.

Carriker, M. A. Jr. (1910). An annotated list of the birds of Costa Rica including Cocos Island. Annals of the Carnegie Museum 4, 314-915. 
Revista Herencia, Vol. 35 (1), enero-junio, 2022.

Carrillo, E., Wong, G. \& Sáenz, J. C. (1999). Mamíferos de Costa Rica. Instituto Nacional de Biodiversidad (INBio).

Casto, S. D. \& Burke, H. R. (2010). Austin Paul Smith; the life of a natural history collector and horticulturalist. Print Express.

Chacón, I. \& Montero, J. (2007). Mariposas de Costa Rica. Instituto Nacional de Biodiversidad (INBio).

Conejo, A. (1975). Henri Pittier. Serie ¿Quién fue y qué hizo? Ministerio de Cultura, Juventud y Deportes.

Cortés, J. \& León, A. (2002). Arrecifes coralinos de Costa Rica. Instituto Nacional de Biodiversidad (INBio).

Dauphin, G. (2020). Adolphe Tonduz y la época de oro de la botánica en Costa Rica. 2 ed. Editorial Tecnológica de Costa Rica.

DeVries, P. J. (1987). The butterflies of Costa Rica and their natural history. Vol. 1. Princeton University Press.

DeVries, P. J. (1997). The butterflies of Costa Rica and their natural history. Vol. 2. Princeton University Press.

Díaz, R. E. (2016). El Instituto Físico-Geográfico y su aporte al desarrollo de la historia natural en Costa Rica (1889-1910). En: Territorio, Recursos Naturales y Ambiente: hacia una historia comparada. Estudio a través de Argentina, México, Costa Rica, Haití, Paraguay, Uruguay y Venezuela. C.E. Lértora (ed.). Fundación para el Estudio del Pensamiento Argentino e Iberoamericano (FEPAI), pp. 315-345.

Díaz, R. E. \& Solano, F. J. (2009). Costa Rica: desarrollo científico; una mirada en su historia natural a través de Paul Biolley Matthey (1886-1908). En: Geonaturalia. Geografía e Historia Natural: hacia una historia comparada. C.E. Lértora (ed.). Fundación para el Estudio del Pensamiento Argentino e Iberoamericano (FEPAI), pp. 209-238.

Eakin, M. C. (1999). The origins of modern science in Costa Rica: The Instituto FísicoGeográfico Nacional, 1887-1904. Latin American Research Review 34(1), 123-150.

Fernández, R. (ed.). (2002). Costa Rica en el siglo XIX; relatos de viajeros. EUNED.

Fernández de Oviedo, G. (1992). Historia general y natural de las Indias. 2 ed. Juan Pérez de Tudela Bueso (ed.). 5 vol. Ediciones Atlas. 
Revista Herencia, Vol. 35 (1), enero-junio, 2022.

García, J. E. (2009). Breve historia de la Escuela de Biología de la Universidad de Costa Rica (1957-2009). Revista de Biología Tropical 57 (Supl. 1), 1-14.

Godoy, C., Miranda, X. \& Nishida, K. (2005). Membrácidos de América tropical. Instituto Nacional de Biodiversidad (INBio).

Gómez, L. D. \& Savage, J. M. (1986). Investigadores en aquella rica costa: biología de campo costarricense 1400-1980. En: Historia natural de Costa Rica. D.H. Janzen (ed.). Editorial de la Universidad de Costa Rica.

González, L. F. (1976). Historia de la influencia extranjera en el desenvolvimiento educacional y científico de Costa Rica. Biblioteca Patria. Editorial Costa Rica.

Goodwin, G. G. 1946. Mammals of Costa Rica. Bulletin American Museum of Natural History 87, 271-473.

Grayum, M. H., Hammel, B. E., Troyo, S. \& Zamora, N. (2004). Historia/History. En: Manual de plantas de Costa Rica. Vol. 1. Introducción. p. 1-50. B.E. Hammel, M.H. Grayum, C. Herrera \& Zamora, N. (eds.). Missouri Botanical Garden, Instituto Nacional de Biodiversidad (INBio) y Museo Nacional de Costa Rica. Monographs Systematic Botany Missouri Botanical Garden 97, 1-300.

Hammel, B. (2005). Plantas ornamentales nativas de Costa Rica. 3 ed. Instituto Nacional de Biodiversidad (INBio).

Hilje, L. (2013a). Trópico agreste; la huella de los naturalistas alemanes en la Costa Rica del siglo XIX. Editorial Tecnológica de Costa Rica.

Hilje, L. (2013b). Los primeros exploradores de la entomofauna costarricense. Brenesia $80,65-88$.

Hilje, L. (2015). Don Juan Rafael Mora y las ciencias naturales en Costa Rica. Editorial Universidad Técnica Nacional (EUTN).

Hilje, L. (2020). La bandera prusiana ondeó en Angostura. Instituto Costarricense de Electricidad.

Holdridge, L. R. (1978). Ecología basada en zonas de vida. IICA.

Holdridge, L. R., Poveda, L. J. \& Jiménez, Q. (1997). Árboles de Costa Rica. Vol. 1. Centro Científico Tropical.

Janzen, D. H. (ed.). (1986). Historia natural de Costa Rica. Editorial de la Universidad de Costa Rica. 
Revista Herencia, Vol. 35 (1), enero-junio, 2022.

Janzen, D. H. \& Hallwachs, W. (2016). DNA barcoding the Lepidoptera inventory of a large complex tropical conserved wildland, Area de Conservación Guanacaste, northwestern Costa Rica. Genome 59(9), 641-660.

Jiménez, A. (2013). El café en Costa Rica: gran modelador del costarricense. Editorial de la Universidad de Costa Rica.

Jiménez, Q. (1999). Árboles maderables en peligro de extinción en Costa Rica. 2 ed. Editorial Instituto Nacional de Biodiversidad (INBio).

Jiménez, Q., Rojas, F. Rojas, V. \& Rodríguez, L. (2011). Árboles maderables de Costa Rica: ecología y silvicultura. 2 ed. Editorial Instituto Nacional de Biodiversidad (INBio).

Jirón, L. F. \& Vargas, R. G. (1986). La entomología en Costa Rica: una reseña histórica. Quipu 3(1), 67-77.

Kandler, C. (1987). Reseña histórica del Museo Nacional. En: Museo Nacional de Costa Rica, más de cien años de historia. Ministerio de Cultura, Juventud y Deportes.

Kapelle, M. (ed.). (2015). Costa Rican ecosystems. The University of Chicago Press.

Kapelle, M. \& Horn, S. (eds.). (2005). Páramos de Costa Rica. Editorial Instituto Nacional de Biodiversidad (INBio).

Kapelle, M., Castro, M. Acevedo, H., González, L. \& Monge, H. (2002). Ecosistemas del Área de Conservación Osa. Editorial Instituto Nacional de Biodiversidad (INBio).

LaVal, R. K. \& Rodríguez, B. (2002). Murciélagos de Costa Rica. Instituto Nacional de Biodiversidad (INBio).

León, J. (2002). La exploración botánica de Costa Rica en el siglo XIX. En: Ciencia y técnica en la Costa Rica del siglo XIX. G. Peraldo (ed.). Editorial Tecnológica de Costa Rica.

Mata, M. (2003). Macrohongos de Costa Rica. Vol. 1. Instituto Nacional de Biodiversidad (INBio).

Mata, M., Halling, R. \& Mueller, G. M. (2003). Macrohongos de Costa Rica. Vol. 2. Instituto Nacional de Biodiversidad (INBio).

May, R. H. (2013). En los pasos de Zeledón. Historia de la ornitología nacional y la Asociación Ornitológica de Costa Rica. Asociación Ornitológica de Costa Rica.

Meagher, T. F. (2002). Vacaciones en Costa Rica. En: Costa Rica en el siglo XIX; relatos de viajeros. R. Fernández Guardia (ed.). EUNED. 
Revista Herencia, Vol. 35 (1), enero-junio, 2022.

Molina, F. (2007). Bosquejo de la República de Costa Rica; seguido de apuntamientos para su historia, con varios mapas, vistas y retratos. Biblioteca de Clásicos de la Historia Costarricense, No. 5. EUNED.

Monge-Nájera, J. \& Méndez-Estrada, V. H. (2002). Dos colosos de la biología costarricense del siglo XIX: Anastasio Alfaro y Henri Pittier. En: Ciencia y técnica en la Costa Rica del siglo XIX. G. Peraldo (ed.). Editorial Tecnológica de Costa Rica.

Morales. F. J. (2000). Bromelias de Costa Rica. 2 ed. Instituto Nacional de Biodiversidad (INBio).

Morales. F. J. (2009). Orquídeas de Costa Rica. 5 vols. Instituto Nacional de Biodiversidad (INBio).

Obando, V. \& Bermúdez, T. (2020). Integración y divulgación del conocimiento sobre la biodiversidad costarricense. Serie 1: Generalidades del Proyecto. UNA-Escuela de Ciencias Biológicas y avances en la integración de cifras de grupos taxonómicos en Costa Rica. UNA-ECB. Primer Boletín Informativo. 14 p.

Obregón, C. (2002). Nuestros gobernantes: verdades del pasado para comprender el futuro. 2 ed. Editorial de la Universidad de Costa Rica.

Obregón, C. (2006). La realidad de un sueño: el Colegio de San Luis Gonzaga de Cartago, 1869-1956. Cincuenta Aniversario de la Graduación de 1956.

Oersted, A. S. (2011). La América Central. J. León (ed.). Editorial de la Universidad de Costa Rica.

Ossenbach, C. (2016). Orquídeas y orquideología en América Central: 500 años de historia. Editorial Tecnológica de Costa Rica.

Pacheco, L. (1972). Mauro Fernández. Serie ¿Quién fue y qué hizo? Ministerio de Cultura, Juventud y Deportes.

Polakowsky, H. (1940). La República de Costa Rica. Revista de los Archivos Nacionales 11-12, 623-639.

Quesada, M. A. (ed.). (2001). Entre silladas y rejoyas; viajeros por Costa Rica de 1850 a 1950. Editorial Tecnológica de Costa Rica.

Quirós, O. (2013). El canciller Gutiérrez Iglesias. Instituto del Servicio Exterior Manuel María de Peralta. Ministerio de Relaciones Exteriores y Culto de Costa Rica. Serie Yvonne Clays No. 12. 
Revista Herencia, Vol. 35 (1), enero-junio, 2022.

Rocha, O. J. \& Braker, E. (2021). The Organization for Tropical Studies: History, accomplishments, future directions in education and research, with an emphasis in the contributions to the study of plant reproductive ecology and genetics in tropical ecosystems. Biological Conservation. https://doi.org/10.1016/j.biocon.2020.108890

Rodríguez, B. (2002). Los taxidermistas del Museo Nacional, su aporte a la zoología de Costa Rica. En: Ciencia y técnica en la Costa Rica del siglo XIX. G. Peraldo (ed.). Editorial Tecnológica de Costa Rica.

Rodríguez, R. L. (2018). Rafael Lucas Rodríguez Caballero: botánico, artista y humanista. Editorial Tecnológica de Costa Rica.

Rojas, F., Bermúdez, G. \& Jiménez, Q. (2016). Plantas ornamentales del trópico. 2 ed. Editorial Tecnológica de Costa Rica.

Sáenz, J. C., Wong, G. \& Carrillo, E. (2004). Ballenas y delfines de América Central. Instituto Nacional de Biodiversidad (INBio).

Salazar, A.H. (2009). Alberto Manuel Brenes: el naturalista. Editorial de la Universidad de Costa Rica.

Savage, J. M. (2002). The amphibians and reptiles of Costa Rica; a herpetofauna between two continents, between to seas. The University of Chicago Press.

Skutch, A.F. (2001). Un naturalista en Costa Rica. Instituto Nacional de Biodiversidad (INBio) y Centro Científico Tropical (CCT).

Slud, P. (1964). The birds of Costa Rica. Bulletin American Museum of Natural History $128,1-430$.

Solís, A. (2002). Escarabajos de Costa Rica. Instituto Nacional de Biodiversidad (INBio).

Solórzano, A. (2004). Serpientes de Costa Rica. Instituto Nacional de Biodiversidad (INBio).

Standley, P.C. (1937-1938). Flora of Costa Rica. Field Museum of Natural History, Botanical Series 18, 1-1616.

Stiles, F. G. \& Skutch, A. F. (1995). Guía de aves de Costa Rica. Instituto Nacional de Biodiversidad (INBio).

Taracena, A. \& Sellen, A. T. (2006). Emanuel von Friedrichsthal (1809-1842): su viaje a América y el debate sobre el origen de la civilización maya. Península 1(2), 49-67.

Torres-Rivas, E. (1989). Interpretación del desarrollo social centroamericano. 12 ed. FLACSO. 
Revista Herencia, Vol. 35 (1), enero-junio, 2022.

Tosi, J. A. (1969). Mapa ecológico de Costa Rica, basado en la clasificación de zonas de vida del mundo de L.R. Holdridge. Centro Científico Tropical.

Ugalde. J. A. (2002). Avispas, abejas y hormigas de Costa Rica. Instituto Nacional de Biodiversidad (INBio).

Umaña, L. \& Sipman, H. (2002). Líquenes de Costa Rica. Instituto Nacional de Biodiversidad (INBio).

Valerio, C. E. (2006). Costa Rica: ambiente y biodiversidad. Editorial Instituto Nacional de Biodiversidad (INBio).

Víquez, C. (1999). Escorpiones de Costa Rica. Instituto Nacional de Biodiversidad (INBio).

Wagner, M. \& Scherzer, C. (1974). La República de Costa Rica en Centro América. Serie Nos Ven No. 2. 2 vol. Ministerio de Cultura, Juventud y Deportes.

Wehrtmann, I. S. \& Cortés, J. (eds.). (2009). Marine biodiversity of Costa Rica, Central America. Monographiae Biologicae. Vol. 86. Springer + Business Media B.V.

Zamora N. \& Pennington, T. D. (2001). Guabas y cuajiniquiles de Costa Rica (Inga spp.). Instituto Nacional de Biodiversidad (INBio).

Zamora, N., Jiménez, Q. \& Poveda, L. J. (2000). Árboles de Costa Rica. Vol. 2. Instituto Nacional de Biodiversidad (INBio).

Zamora, N., Jiménez, Q. \& Poveda, L. J. (2003). Árboles de Costa Rica. Vol. 3. Instituto Nacional de Biodiversidad (INBio).

Zamora, N., Jiménez, Q. \& Poveda, L. J. (2017). Árboles de Costa Rica. Vol. 4. Editorial Tecnológica de Costa Rica.

Zelaya, C. (1973). Rafael Francisco Osejo. Serie ¿Quién fue y qué hizo? Ministerio de Cultura, Juventud y Deportes.

Zeledón, R. (2004). La ciencia y la tecnología. En: Costa Rica en el Siglo XX. Tomo II. E. Rodríguez (ed.). Editorial Universidad Estatal a Distancia.

Zumbado, M. (1999). Dípteros de Costa Rica. Instituto Nacional de Biodiversidad (INBio).

Zumbado, M. (2006). Dípteros de Costa Rica y la América tropical. Instituto Nacional de Biodiversidad (INBio). 